\title{
Silurian carbonate high-energy deposits of potential tsunami origin: distinguishing lateral redeposition and time averaging using carbon isotope chemostratigraphy
}

\section{Emilia Jarochowska and Axel Munnecke}

GeoZentrum Nordbayern, Fachgruppe Paläoumwelt, Friedrich-AlexanderUniversität Erlangen-Nürnberg, Loewenichstr. 28, 91054 Erlangen, Germany; Tel. +4991318524789; Fax +4991318524840

\section{CORRESPONDING AUTHOR, E-MAIL: EMILIA.JAROCHOWSKA@FAU.DE}

This is a postprint of a peer-reviewed article published in Sedimentary Geology. Please use the following citation:

Jarochowska, E., \& Munnecke, A. (2015). Silurian carbonate high-energy deposits of potential tsunami origin: Distinguishing lateral redeposition and time averaging using carbon isotope chemostratigraphy. Sedimentary Geology, 315, 14-28.

https://doi.org/10.1016/j.sedgeo.2014.10.012

Abstract: Stable carbon isotope curves are used as a precise stratigraphic tool in the Paleozoic, even though they are commonly based on shallow-water carbonate record, characterized by low stratigraphic completeness. Identification of episodes of large-scale redeposition and erosion may improve $\delta^{13} \mathrm{C}_{\text {carb- }}$ based correlations. Here, a series of at least three episodes of high-energy onshore redeposition are described from the Makarivka Member (new unit) of the Ustya Formation from the Homerian (middle 
Silurian) of Podolia, Ukraine. The Makarivka Member is emplaced within a tidal flat succession. Its most prominent part is divided into a lower polymictic conglomerate of sand- to boulder-sized clasts representing a range of subtidal facies, and an upper heterolithic unit composed of grainstone and mudstone laminae. The aim of the study is to identify the mechanism of deposition of the allochthonous conglomeratic material in this Member. Based on analogies with Recent tsunami deposits, the conglomerate is interpreted to reflect the strongest landward-directed current in the tsunami run-up phase, and the heterolith - alternating high-density landward currents, stagnant intervals allowing mud and land-derived debris to settle, and backwash flows. The tsunamite was deposited during an interval of decreasing isotopic values of the Mulde Excursion, a global $\delta^{13} \mathrm{C}$ excursion reaching $+5.2 \%$ in the studied sections. Clast redeposition in an interval characterized by rapidly changing $\delta^{13} C_{\text {carb }}$ offers the opportunity to evaluate the degree of temporal and spatial averaging caused by the tsunami. The clasts in the polymictic conglomerate show scattered $\delta^{13} \mathrm{C}_{\text {carb }}$ values $(-0.3 \%$ to $+2.1 \%$ ) compared to homogenous $\left(1.3 \%\right.$ o to $1.6 \%$ ) values in the matrix. The presence of clasts characterized by low $\delta^{13} \mathrm{C}_{\text {carb }}$ values is explained by their decrease with bathymetry rather than erosion of pre-excursion strata, whereas high values characterize material entrained from the sea-floor and strata directly underlying the tsunamite. Close $(1.3 \%$ and $1.5 \%)$ average $\delta^{13} C_{\text {carb }}$ values suggest that the matrix of the conglomerate is potentially a product of clast grinding.

Keywors: Wenlock, Homerian, positive carbon isotope excursion, temporal mixing, Baltic Basin, transgressive lag, sequence stratigraphy

\section{Introduction}

The term "time averaging" is most commonly employed with reference to accumulations that contain fossils mixed over time intervals exceeding the life span of organisms (Kowalewski and Bambach, 2008). Inorganic particles are subject to this process in the same extent as fossils, and in fact every sedimentological record is time-averaged (Kowalewski, 1996). The absolute extent of time averaging in the geological record is difficult to estimate, with the exception of situations where sedimentary particles are themselves carriers of time information (e.g., Kowalewski and Rimstidt, 2003). The process of temporal mixing may affect $\delta^{13} \mathrm{C}$-based chemostratigraphic correlations, which - particularly in the 
Paleozoic - are considered to often provide the highest temporal resolution available (e.g., Cramer et al., 2010a; 2010b; Sadler, 2012). At the same time, the majority of the $\delta^{13} \mathrm{C}$ chemostratigraphic record is derived from shallow-water carbonates, which are subject to intensive erosion and redeposition. Recognition of the influence of these processes on carbon isotope curves employed for correlations may help improve these correlations and refine their stratigraphic resolution by constraining the temporal extent of gaps which cannot be evaluated using less sensitive stratigraphic tools such as biostratigraphy.

The present study describes an example of large-scale redeposition of allochthonous material in a shallow-marine carbonate succession of the middle Silurian in Ukraine. Based on the sedimentological documentation presented below, potential mechanisms responsible for the formation of the high-energy deposit belonging to the newly introduced Makarivka Member are discussed. The Makarivka Member was deposited during an interval of lowering isotopic values of the Mulde positive carbon isotope excursion (CIE) and includes a polymictic conglomerate, which contains boulders of various lithologies occurring across the excursion interval. The high rate of $\delta^{13} \mathrm{C}_{\text {carb }}$ change in a short interval provides an opportunity to evaluate the degree of time averaging, as well as its potential effect on the shape of the $\delta^{13} \mathrm{C}$ curve and correlations based on it.

The first aim of the study is to identify the mechanism which has led to redeposition and mixing of clasts representing a variety of lithologies from subtidal facies in the Makarivka Member. Four possibilities are considered: landward transport of clasts by 1) a hurricane or 2) a tsunami, 3) transport of clasts from an uplifted area located landward to the site of deposition, e.g. by a stream flood, and 4) mixing of clasts of different facies and ages in a transgressive lag. The identification of the depositional process is based on the stratigraphic position of the Makarivka Member, on the direction of transport, and on comparison with sedimentary structures observed in modern hurricane and tsunami deposits.

The second aim is to evaluate the scale of time- and space-averaging of $\delta^{13} C_{\text {carb }}$ values in the polymictic conglomerate in the Makarivka Member in comparison to the general trend of the ${ }^{13} C_{\text {carb }}$ development in the uppermost part of the Mulde $\mathrm{CIE}$, and to use the clasts' $\delta^{13} \mathrm{C}_{\text {carb }}$ values to identify the point on the Mulde $\delta^{13} \mathrm{C}$ curve to which they correspond, and thus the temporal or spatial scale of redeposition. 


\section{Geological setting}

The Silurian succession in Podolia, Ukraine, represents deposits of a carbonate ramp developed in a low-relief epicontinental basin, which stretched during the Silurian along the western shelf of the paleocontinent of Baltica (Figs 1 and 2) from present-day Scandinavia to Moldova (Poprawa et al., 1999). In Podolia, Silurian rocks are exposed in deep canyons of the Dniester River and its tributaries. They comprise a succession starting in the uppermost Llandovery and continuing without major stratigraphic breaks into the Devonian (Nikiforova et al., 1972; Tsegelnyuk et al., 1983; Racki et al., 2012).

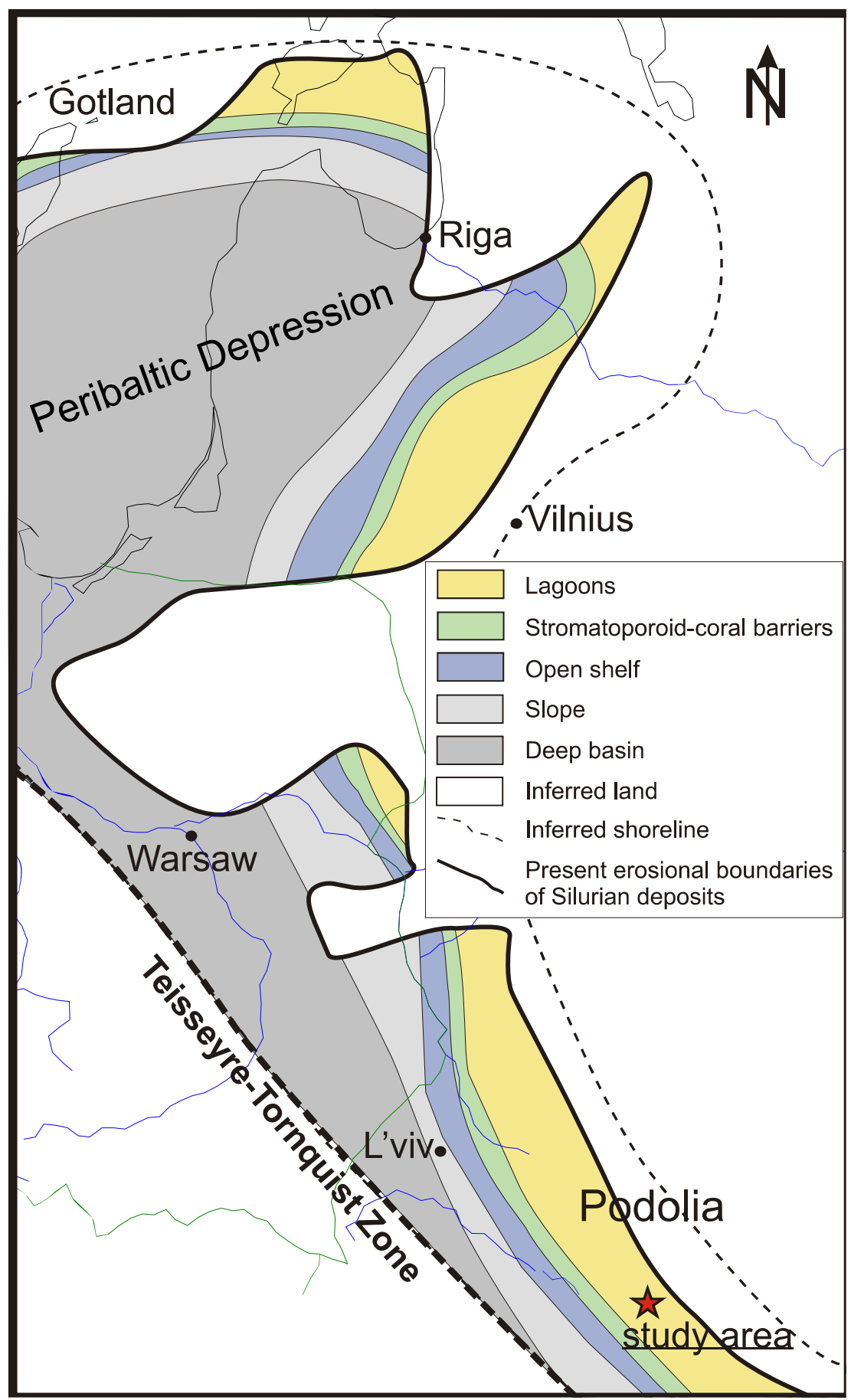




\section{FIGURE 1. PALEOgEOgRAPHICAL MAP OF THE BALTIC BASIN ON THE SHELF OF BALTICA DURING THE MIDDLE} Silurian (Gothograptus nassa Chron). After Einasto et Al. (1986) ANd Teller (1997).

\subsection{Stratigraphy}

Following the lithostratigraphic scheme of Tsegelnyuk et al. (1983) adapted according to the recommendations of the International Commission on Stratigraphy, the Homerian in Podolia is represented by the Ternava, Muksha and Ustya formations of the Yaruga Group (Fig. 3). The Muksha and lowermost Ustya formations record a pronounced (up to $+5.2 \%$ ) positive carbon isotope excursion (Kaljo et al., 2007; Jarochowska et al., 2014), known as the Mulde excursion, which allows correlations with other regions. It is recorded in the carbonate platform in Gotland (Samtleben et al., 2000; +3.2\%o; Calner et al., 2006; +3.8\%o; Calner et al., 2012; +2.6\%o), Lithuania (Martma et al., 2005; +1.6\%o), Latvia and Estonia (Kaljo et al., 1997; Kaljo and Martma, 2006; $+4.6 \%$ ), in open shelf environments in the subsurface Poland (Porębska et al., 2004; +0.6\%o), in the Anglo-Welsh Basin (Corfield et al., 1992; Marshall et al., 2012; +5.5\%o), in the peri-Gondwanan Prague Basin (Frýda and Frýdová, 2014; +3.2\%o), in USA (Cramer et al., 2006; +2.6\%o) and in Arctic Canada (Noble et al., 2005; Noble et al., 2012; shifts up to +3.4\%o). The age of the Mulde $\mathrm{CIE}$ has been constrained with ${ }^{206} \mathrm{~Pb} /{ }^{238} \mathrm{U}$ (zircon) dating to $428.45 \pm 0.73 \mathrm{Ma}$ to $427.86 \pm$ $0.71 \mathrm{Ma}$, indicating its duration to be shorter than $1 \mathrm{Myr}$. (Cramer et al., 2012). Conodont biostratigraphy based on Gotland (Calner and Jeppsson, 2003; Jeppsson and Calner, 2003) indicates that the onset of the excursion is close to the boundary between the Ozarkodina sagitta sagitta and the $O$. bohemica longa conodont zones, the rising limb of the second peak of the CIE starts within the Kockelella ortus absidata conodont zone, and the return of the $\delta^{13} C_{\text {carb }}$ values to the baseline level is, depending on the amplitude of the excursion in different sections, placed within this zone or in the following Ctenognathodus murchisoni conodont zone. In the Dniester River Valley the end of the excursion falls in the lower part of the Ustya Formation, above the Makarivka Member, indicating its late Homerian age (Jarochowska et al., 2014). 


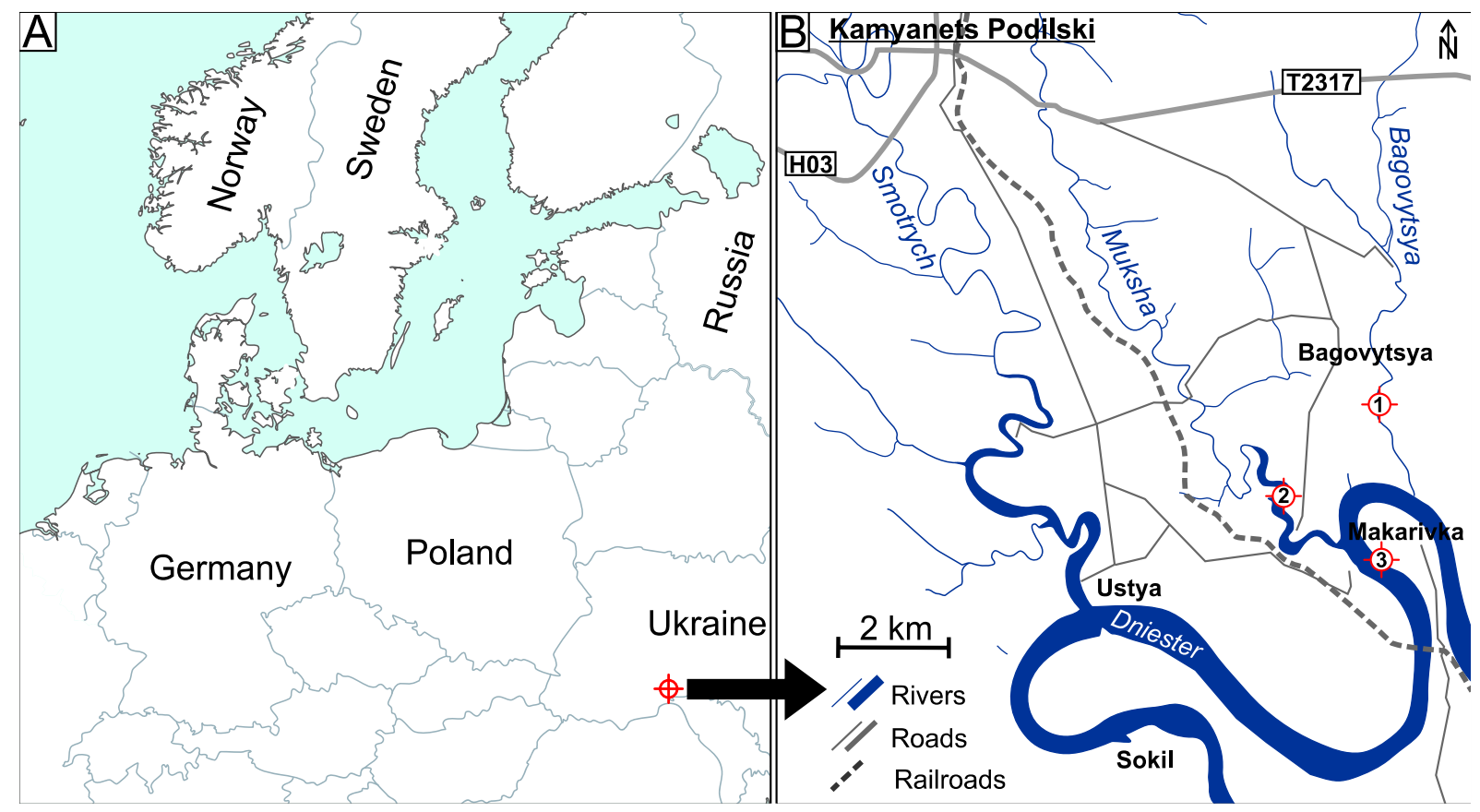

Figure 2. Study area: (A) Present-day position; (B) Discussed sections in the Dniester River Valley: 1 - BAGOVYTSYA, 2 - MUKSHA 2, 3 - MAKARIVKA.

\subsection{Study locations}

The Makarivka Member occurs in two aspects: the more complete, proximal with respect to the source of allochthonous material aspect, exposed in the Makarivka section $\left(\varphi 48^{\circ} 34^{\prime} 13.80^{\prime \prime} \mathrm{N}\right.$, $\lambda 26^{\circ} 44^{\prime} 18.50^{\prime \prime} E$, Figs 2 and 4A), which is located in the southern bank of the Dniester River, and in a distal, less complete aspect, lacking some of the lithological types present in Makarivka (sections 4.2.1 and 4.2.2), in the Bagovytsya ( $\varphi$ 48 $36^{\prime} 21.00^{\prime \prime} N ; \lambda 26^{\circ} 43^{\prime} 45.50^{\prime \prime} \mathrm{E}$ ) and Muksha 2 ( $\varphi 48^{\circ} 35^{\prime} 13.90^{\prime \prime} N ; \lambda$ $\left.26^{\circ} 42^{\prime} 3.90^{\prime \prime} E\right)$ sections located in valley slope ravines of the northern tributaries of the Dniester River (Figs 2 and 4). The name of the Makarivka Member is derived from the village of Makarivka, Chernivtsi administrative region, western Ukraine. The type locality is a 200-m-long exposure along the southern bank of the Dniester River, located $300 \mathrm{~m}$ to the west of the village. 


\begin{tabular}{|c|c|c|c|c|c|c|}
\hline \multicolumn{3}{|c|}{ Tsegelnyuk et al. (1983) } & & \multirow{2}{*}{\multicolumn{2}{|c|}{ This study }} & \\
\hline \multicolumn{2}{|c|}{ Series Formation } & \multicolumn{2}{|l|}{ Subformation } & & & \\
\hline \multirow{4}{*}{ 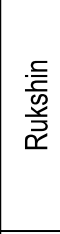 } & Zvenigorod & & \multirow{4}{*}{ 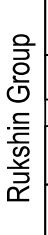 } & \multicolumn{2}{|c|}{ Dzvenygorod Fm. } & $戸$ \\
\hline & Trubchin & & & & chyn Fm. & 음 \\
\hline & Varnitsa & & & $\mathrm{Va}$ & ytsya Fm. & \\
\hline & Prigorodok & & & Pry & rodok Fm. & \\
\hline \multirow{5}{*}{ 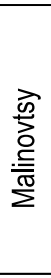 } & \multirow[t]{2}{*}{ 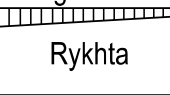 } & \multirow{2}{*}{$\begin{array}{l}\text { Isakovts } \\
\text { Grinchuk }\end{array}$} & \multirow{5}{*}{ 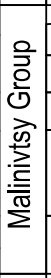 } & (1) & Isakivtsy Fm. & \\
\hline & & & & & & 3 \\
\hline & \multirow{2}{*}{ Tsviklevtsy } & Bernovo & & \multicolumn{2}{|c|}{ Bernovo Fm. } & 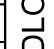 \\
\hline & & Sokol & & \multicolumn{2}{|c|}{ Sokil Fm. } & 3 \\
\hline & Konovka & $\begin{array}{c}\text { Shutnovtsy } \\
\text { Goloskov }\end{array}$ & & \multicolumn{3}{|c|}{\begin{tabular}{|l|l|} 
Konovka Fm. & Shutnivtsy Mb \\
\cline { 2 - 3 } & Goloskov Mb \\
\end{tabular}} \\
\hline \multirow{7}{*}{ 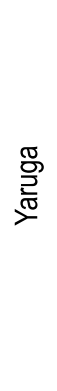 } & \multirow{2}{*}{ Bagovitsa } & Ustje & \multirow{7}{*}{ 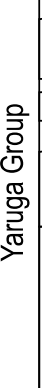 } & & tya Fm. & \\
\hline & & Muksha & & $\begin{array}{l}M \\
M\end{array}$ & sha Fm. & \\
\hline & \multirow{3}{*}{ Ternava } & \multirow{2}{*}{ Sursha } & & \multirow{2}{*}{$\begin{array}{c}\text { Ternava } \\
\text { Fm. }\end{array}$} & Sursha Mb. & 多 \\
\hline & & & & & Vrublivtsy Mb. & \multirow{3}{*}{$\begin{array}{l}y \\
c \\
z \\
3\end{array}$} \\
\hline & & Vrublevtsy & & \multirow{3}{*}{ 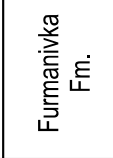 } & Maryanivka Mb. & \\
\hline & \multirow[t]{2}{*}{ Furmanovka } & Demshin & & & Demshin Mb. & \\
\hline & & Restevo & & & Restiv Mb. & \\
\hline
\end{tabular}

FIGURE 3. StRATIgRAPHY OF THE WENLOCK THROUGH PŘídOlí STRATA IN PODOLIA. THE SCHEME USED IN THE PRESENT STUDY INTEGRATES THE ORIGINAL STRATIGRAPHY OF TSEGELNYUK ET AL. (1983) WITH MORE RECENT STUDIES (JAROCHOWSKA AND KOZŁOWSKI, 2014; RACKI ET AL., 2012) AND THE AUTHORS' OWN UNPUBLISHED CONOdONT BIOSTRATIGRAPHIC DATA. POSITION OF THE MAKARIVKA MB. WITHIN THE USTYA FM. IS MARKED IN GREY.

\section{Methods}

\subsection{Sample collection and processing}

The Makarivka, Bagovytsya and Muksha 2 sections were logged for the construction of lithological columns (Fig. 5). In Makarivka, individual beds have been also measured laterally along the distance of $200 \mathrm{~m}$ and their thickness relationships were plotted in Figure 6. The localities were sampled at regular intervals for thin sections and, except for Muksha 2, carbon and oxygen isotope analyses (see Table 2 and Jarochowska et al. 2014). Care has been taken to avoid sample collecting in the proximity of veins, cracks and slickensides. Lithologic descriptions were based on macroscopic observations and 72 thin sections. 

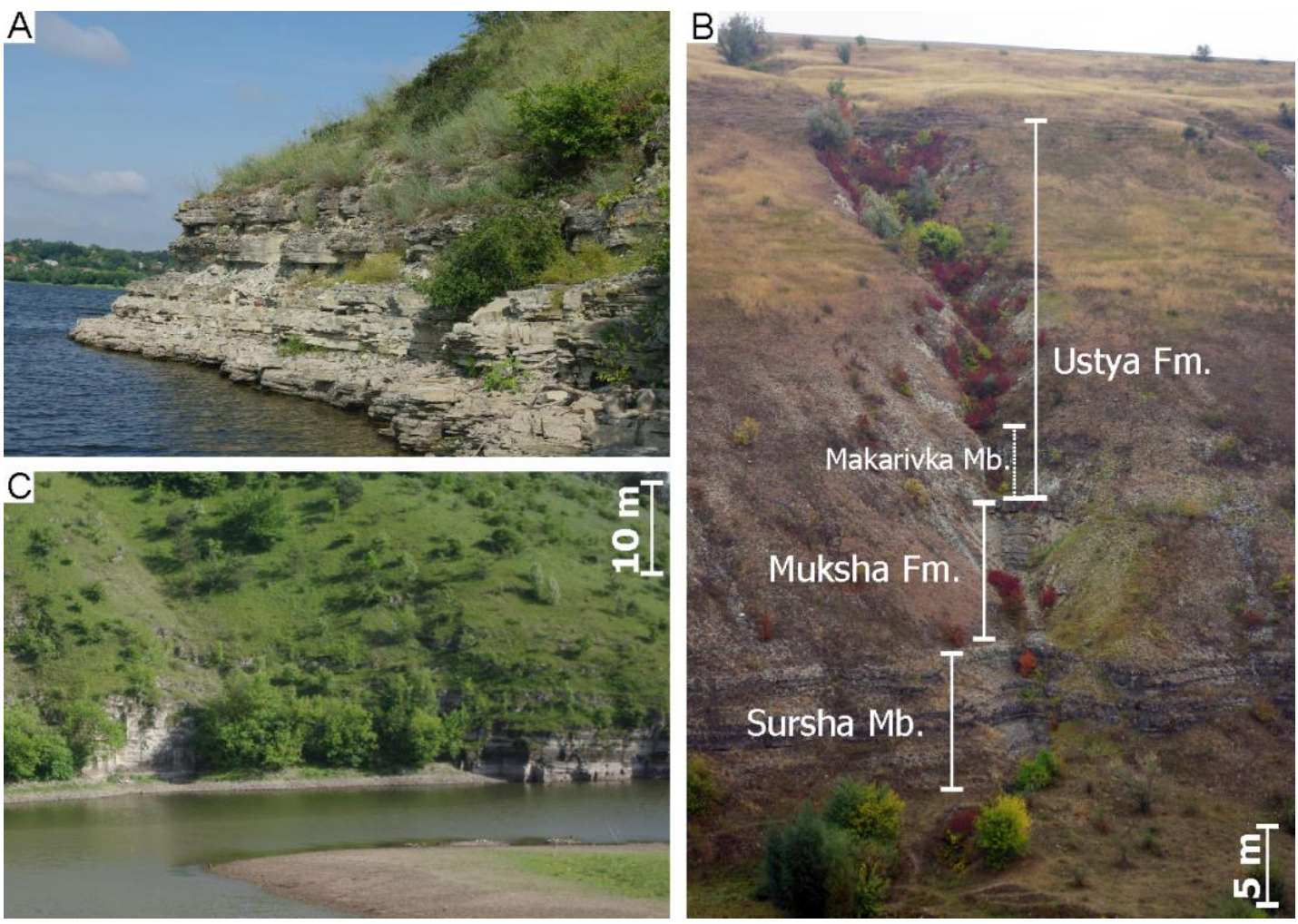

FIGURE 4. OUtCROPS OVERVIEW: (A) MAKARIVKA, THE HEIGHT OF THE OUTCROP IS 4 M; (B) BAgOVYTSYA; (C) MUKSHA 2.

\subsection{Measurement of clast orientation in the conglomerate bed}

The orientation of clasts in the conglomerate bed exposed in the Makarivka section (Fig. 6) was

measured on vertical weathered surfaces as the inclination of the longest axis of each clast. For clasts with circular cross-sections a zero angle was taken. Rose diagrams were plotted using the PAST software (Hammer et al., 2001). Given that the strike of the conglomerate lithosome is not known, it was not possible to measure precisely in the direction of clast transport, but from the general paleogeography (Fig. 1) and overview geological maps (Nikiforova et al., 1972; Tsegelnyuk et al., 1983) it is inferred that the Makarivka exposure is oriented appoximately parallel to the strike, and the measured surfaces were oblique to this direction. This allows estimating the dominant direction of clast inclination, but not its real angle.

\subsection{Carbon and oxygen isotope analyses}

To measure the offset between the $\delta^{13} C_{\text {carb }}$ values in redeposited material and in the matrix of the polymictic conglomerate, bulk-rock carbonate powder was drilled from clasts and from the matrix (16 and 17 data points respectively). The analyses were performed in the stable isotope laboratory of the GeoZentrum Nordbayern, Erlangen, Germany. Carbonate powders were reacted with 103\% phosphoric 
acid at $70^{\circ} \mathrm{C}$ using a Gasbench II connected to a ThermoFinnigan Five Plus mass spectrometer. All values are reported in per mil relative to $\mathrm{V}$-PDB by assigning $\delta^{13} \mathrm{C}$ values $+1.95 \%$ and $-46.6 \%$ o to international standards NBS19 and LSVEC, respectively. Reproducibility and accuracy were monitored by replicate analysis of laboratory standards calibrated to NBS19 and LSVEC and was better than $\pm 0.06 \%$. The results are provided in Table 1. Carbon isotope values throughout the Makarivka section were obtained from freshly cut, unweathered bulk rock samples, and are given in Table 2. Details on the isotope curve for the Bagovytsya section have been provided by Jarochowska et al., (2014).

Additionally, three polished slabs were produced from conglomerate samples collected in Makarivka (Figs 5 and 6 ) by embedding in resin under vacuum. Polished surfaces were scanned to document the points, in which powder samples have been drilled for isotope analyses. Subsequently, the slabs were used to produce thin sections and stain them for dolomite using Alizarin red $0.2 \% \mathrm{w} / \mathrm{v}$ solution for $20 \mathrm{~s}$ according to the method of Friedman (1959). 


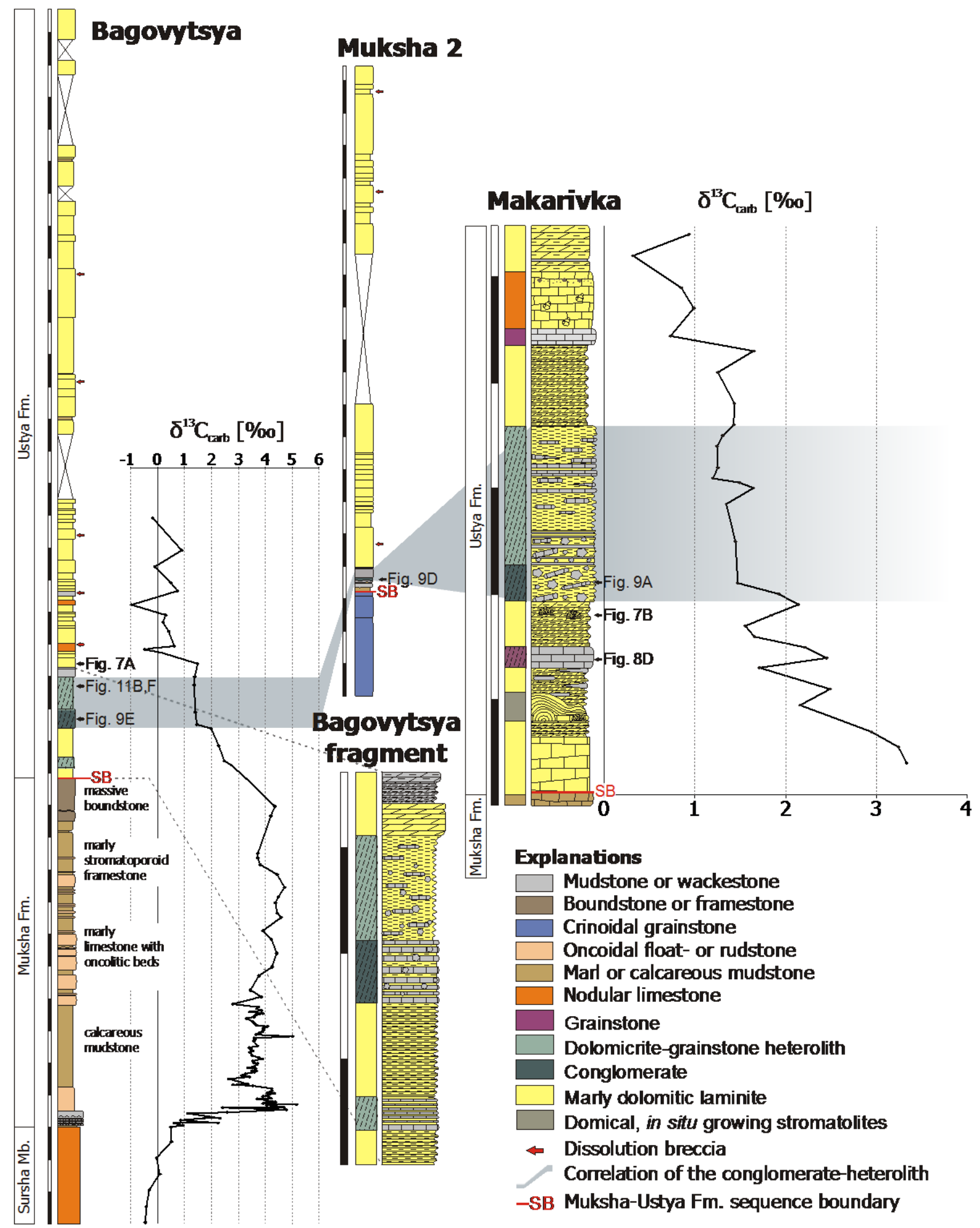

FIGURE 5. LITHOLOGICAL LOGS OF THE STUdied SECTIONS AND $\triangle{ }^{13} \mathrm{C}_{\text {CARB }}$ CURVES FOR THE BAGOVYTSYA AND MAKARIVKA INTERVALS. COLOR CODING OF SECTIONS CORRESPONDS TO FIG. 6 AND REPRESENTS DIFFERENT LITHOLOGICAL TYPES WITHIN THE STUDIED SUCCESSION. DASHED PATTERN MARKS THE MAKARIVKA MEMBER. 


\section{Results}

\subsection{The Ustya Formation - Sedimentary Context of the Makarivka Member}

The studied interval overlies the trangressive succession of the Muksha Formation, which

terminates in microbial-stromatoporoid mud-mounds and oncolitic marls (Jarochowska et al., 2014). The

Makarivka Member is located in the lowermost part of the Ustya Formation and individual beds

representing the member intercalate laterally with lithology dominant in this Formation (Figs 5 and 6).

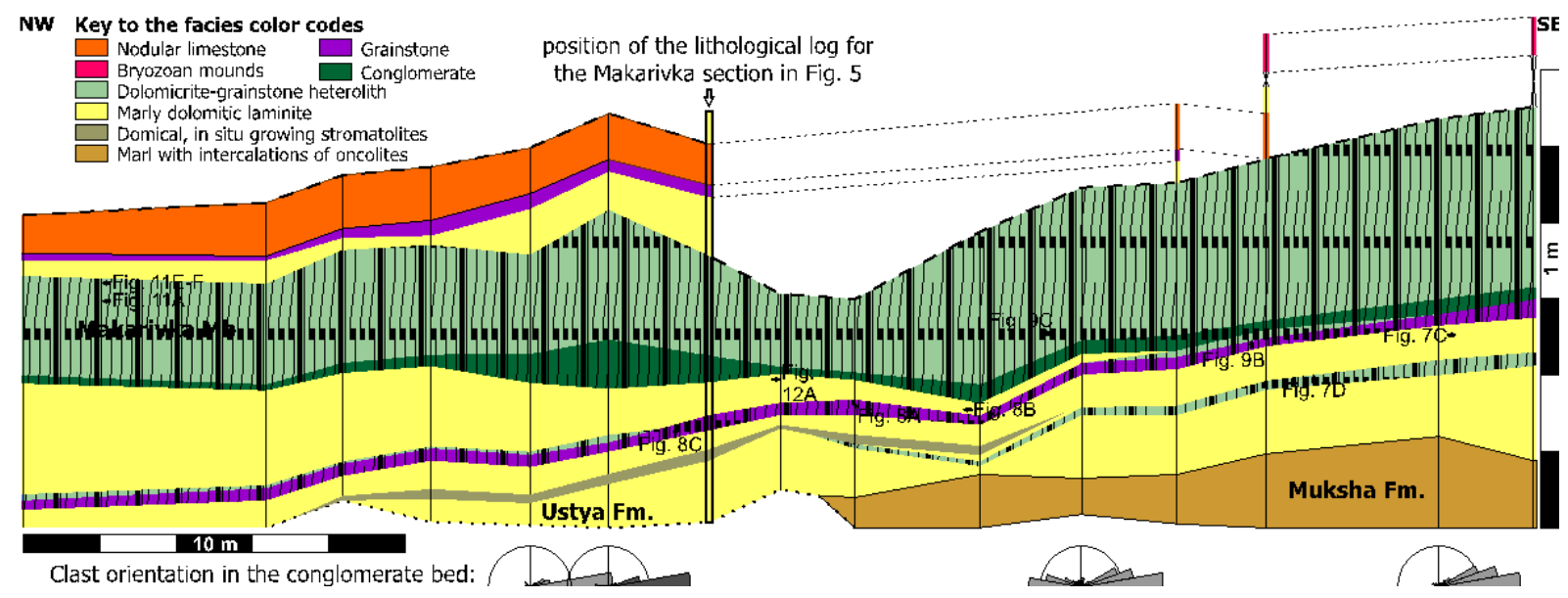

FIGURE 6. LATERAL VIEW Of THE MAKARIVKA MEMBER TYPe LOCALITY. COLORS REPRESENT LITHOLOGIES DISCUSSED IN THE TEXT. ROSE DIAGRAMS SHOW THE DISTRIBUTION OF CLAST ORIENTATION IN THE CONGLOMERATE BED.

The Ustya Formation is composed of up to $24 \mathrm{~m}$ of yellow argillaceous dolomicrite with microbial laminations, which show very little or no disturbance through bioturbation (Fig. 7A-B). Parasequences can be identified based on changes in bedding thickness from thick (up to $30 \mathrm{~cm}$ ) to thin (1 cm), and an increase in the proportion of desiccation cracks towards the top of each parasequence (Fig. 7C). Many parasequences are capped with dissolution surfaces consisting of iron oxide-enriched claystone. The dolomicrites are nearly devoid of fossils, with the exception of sparse intercalations of nodular limestones containing peloids, brachiopods, gastropods and bryozoans, and a lens of bryozoan-microbial mound in the Makarivka section (Fig. 5). In the lower part of this section, a single level of in situ domical stromatolites occurs, with the individual stromatolites reaching the diameter of $50 \mathrm{~cm}$ and the height of $30 \mathrm{~cm}$ (Fig. 7D). 

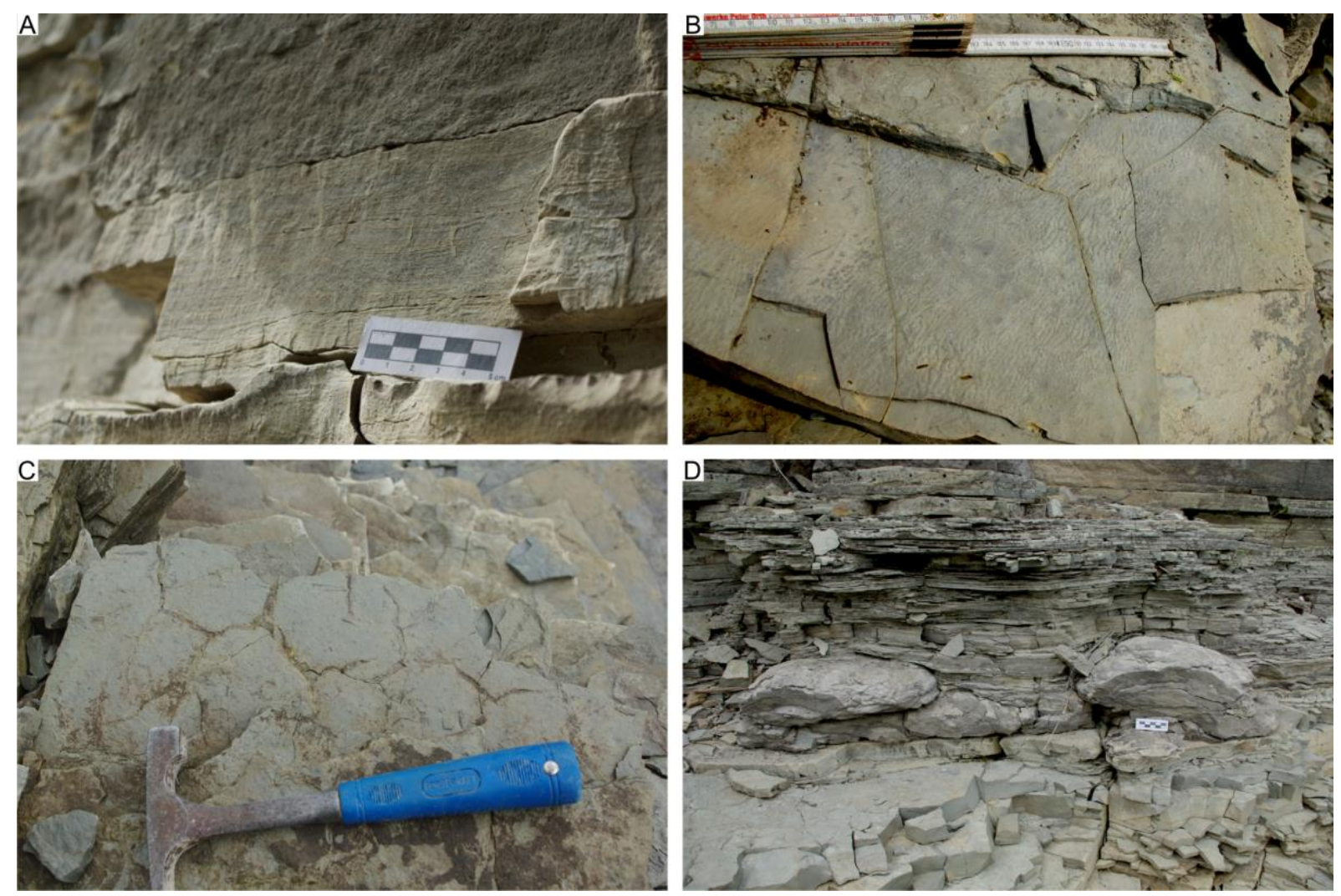

FIGURE 7. LITHOLOGY OF THE USTYA FORMATION: (A) MICROBIAL LAMINATION ON A WEATHERED SURFACE, BAgOVYTSYA; (B) WrinkLE STRUCTURES ON A BEDDING PLANE, MAKARIVKA; (C) BEDDING PLANE WITH DESICCATION CRACKS, MAKARIVKA; (D) DOMICAL STROMATOLITES IN MAKARIVKA.

The interval of the Ustya Formation below the conglomerate contains cobble-sized rip-up clasts emplaced within the dolomitic laminite (Fig. 8A), checkerboard-like crack network (Fig. 8B), and cuneiform cracks (Fig. 9C), both distinct from typical mudcracks present in many layers throughout the Ustya Formation (Fig. 7C). The angular crack network is confined to several beds in the lower part of the Ustya Formation, and continues on freshly exposed surfaces, excluding its formation through weathering. 

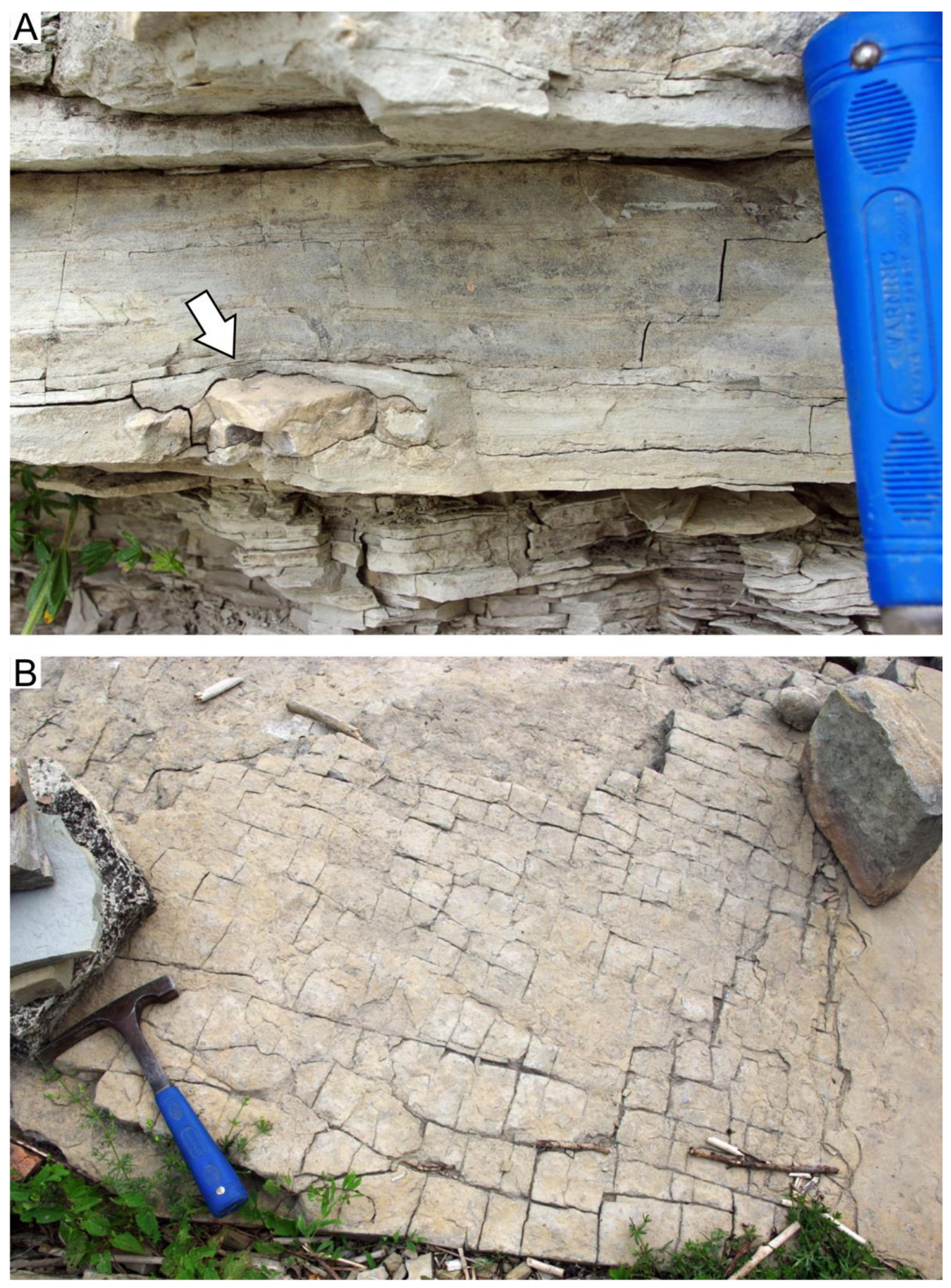

FIGURE 8. SEDIMENTARY STRUCTURES IN THE ARGILLACEOUS DOLOMICRITES IN THE LOWERMOST USTYA FORMATION THAT MAY INDICATE SYNSEDIMENTARY DEFORMATION: (A) LARGE (MIN. 7 CM WIDE) RIP-UP DOLOMICRITE CLAST DRIVEN INTO BEDDED DOLOMICRITE (ARROW). HAMMER FOR SCALE; (B) CHECKERBOARDLIKE CRACK NETWORK. HAMMER FOR SCALE. 


\subsection{Lithological types within the Makarivka Member}

The Makarivka Member (new unit) is distinguished from the surrounding Ustya Formation as beds of allochthonous material developed as three lithological types: grainstone (Fig. 9), polymictic conglomerate (Fig. 10), and dolomicrite-grainstone heterolith (Fig. 12), which are described in detail below. Their lateral extent and variability is shown in Figure 6, where different lithologies are schematically represented with different colors. The thickness of the member varies between 1.6 and 3.7 $\mathrm{m}$ in studied sections. In the type locality, a single polymictic conglomerate bed ranging in thickness from 8 to $65 \mathrm{~cm}$ and overlain by a $1.35-2.35 \mathrm{~m}$ thick heterolith bed continue across the exposure, and can be observed with decreasing thicknesses in Bagovytsya and Muksha 2 respectively. The lower contact of the conglomerate is erosional, cut into an up to $1.45 \mathrm{~m}$ thick bed of argillaceous dolomicrite of the Ustya Formation (NW side of the type locality), into an underlying, discontinuous heterolithic bed (middle heterolith of Tab. 3), or into a grainstone bed (lower grainstone of Tab. 3). The grainstone bed is continuous across the exposure in Makarivka, but has not been observed in other sections, and is overlain by discontinuous, thin (up to $12 \mathrm{~cm}$ ) heterolithic lenses or directly by dolomicrite. The three types of lithology are laterally variable (Tab. 3), with proximal facies characterized by greater thickness and coarser material (Fig. 10A-C); the distal facies is thinner, composed of finer material, and more homogenous. The distal aspect of the Makarivka Member is visible in the Muksha 2 section as sparse rip-up clasts of allochthonous material within the dolomite characteristic for the Ustya Formation (Fig. 10D). The proximal aspect includes additionally a conglomerate bed (Fig. 10A-C) and a grainstone bed (Fig. 9), which are visible in the Bagovytsya (2.8 $\mathrm{m}$ ) and in Makarivka ( $3.4 \mathrm{~m}$; Figs 5 and 6 ) sections. 

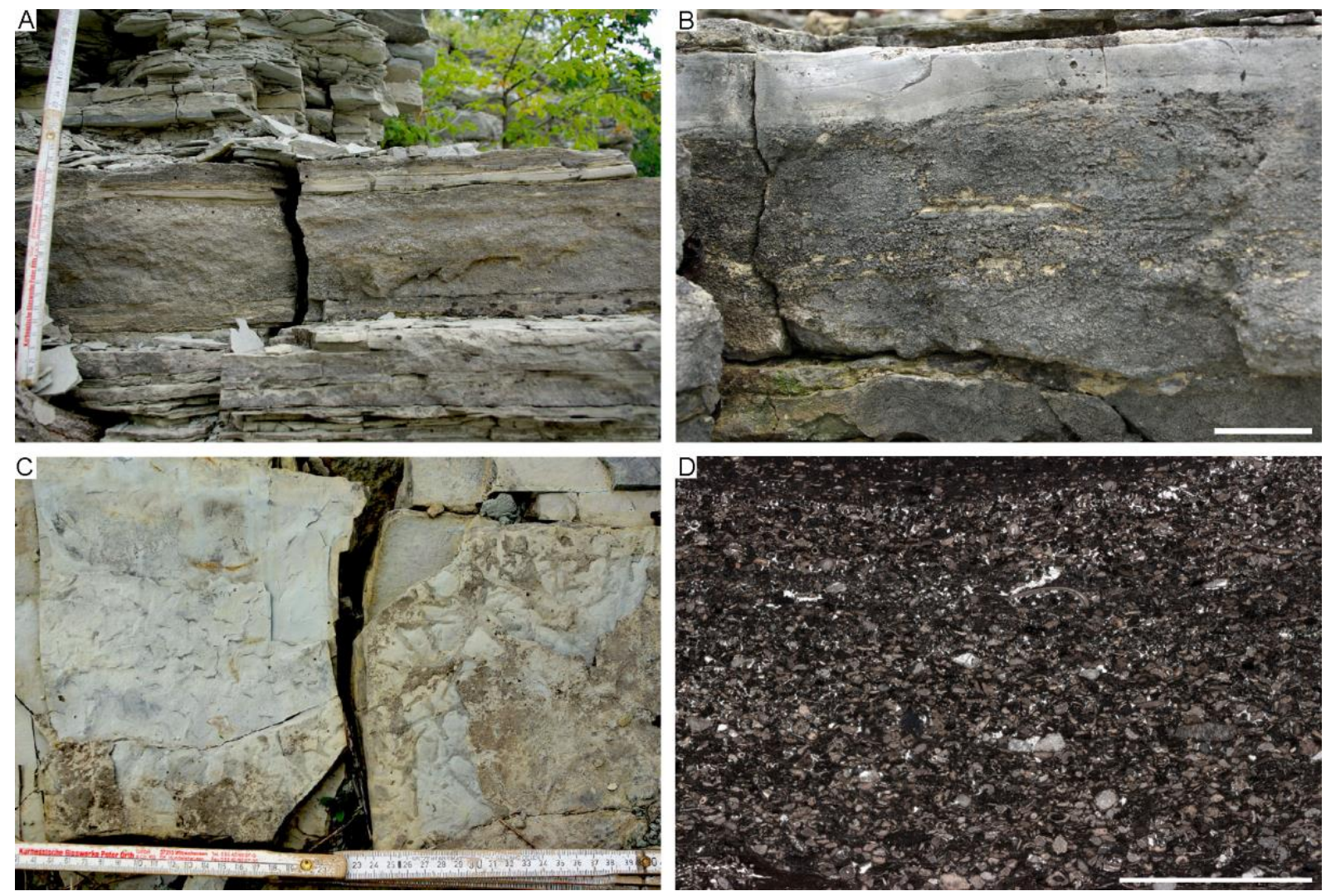

FIGURE 9. GRAINSTONE BEDS IN THE MAKARIVKA SECTION: (A) MASSIVE GRAINSTONE BED WITH EROSIONAL UPPER AND LOWER BOUNDARIES, THICKNESS 16 CM; (B) EROSIONAL CONTACT BETWEEN THE GRAINSTONE BED WITH HORIZONTALLY ALIGNED MUDSTONE RIP-UP CLASTS, AND AN OVERLYING DOLOMICRITE BED WITH MECHANICAL LAMINATION INDICATED BY INTERNAL EROSIONAL BOUNDARIES WITHIN THE DOLOMICRITE BED. SCALE 5 CM; (C) THE SURFACE OF THE DOLOMICRITIC UNIT UNDERLYING THE GRAINSTONE BED, SHOWING A SYSTEM OF CUNEIFORM CRACKS ON MULTIPLE BEDDING PLANES (LEFT), AND PLANOLITES-LIKE BURROWS FILLED WITH GRAINSTONE MATERIAL AT THE CONTACT BETWEEN THE DOLOMICRITE AND GRAINSTONE (RIGHT). MEASURING TAPE SHOWS SCALE IN CENTIMETRES; (D) REPRESENTATIVE MICROFACIES OF THE GRAINSTONE BED: TIGHTLY-PACKED, MODERATELY SORTED, POORLY WASHED CRINOIDAL GRAINSTONE WITH ADMIXTURE OF OSTRACOD SHELLS AND ABRADED FRAGMENTS OF TABULATE CORALS. SCALE 1 CM.

The main objects of the discussion concerning the mechanism of deposition of the allochthonous material in this study are the polymictic conglomerate and the overlying heterolith. The underlying grainstone and heterolith beds are lithologically similar to the above, and clearly distinguished from the dominant lithology of the Ustya Formation - they are therefore included in the Makarivka Member, and their genetic relationships to the conglomerate are discussed below. 

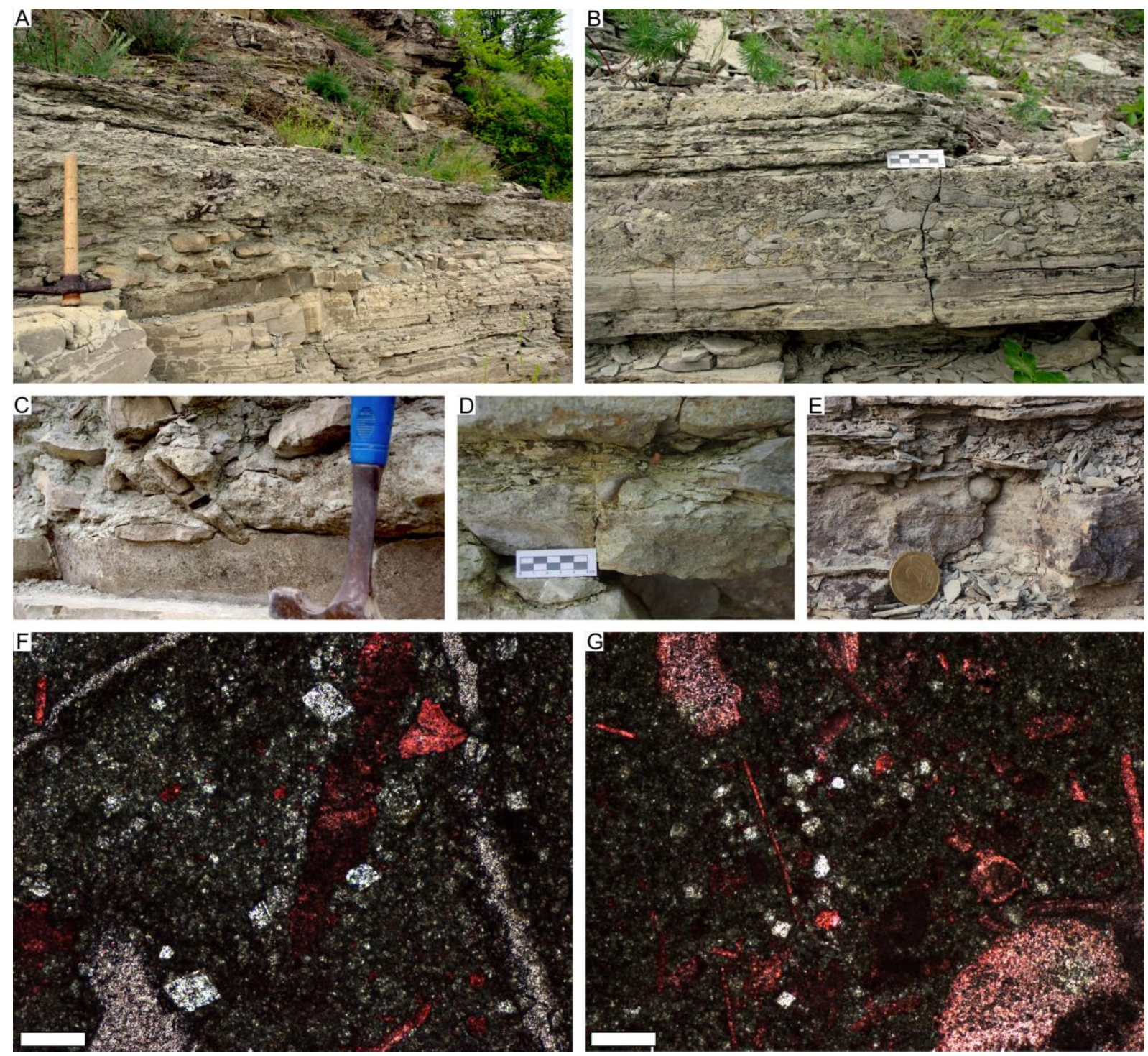

FIGURE 10. Conglomerate bed of the Makarivka Member: (A) Boulder-Size RIP-UP CLASTS IN MAKARIVKA; (B) WEATHERED SURFACES EXPOSING ANGULAR IMBRICATED CLASTS, MAKARIVKA. SCALE IS 5 CM; (C) LITHOCLASTS DRIVEN INTO THE UNDERLYING DOLOMICRITIC BED, MAKARIVKA; (D-E) DISTAL ASPECT OF THE CONGLOMERATE BED: SINGLE, WELL-ROUNDED WACKESTONE LITHOCLASTS FLOATING IN FINE-GRAINED heterolith; (D) MuKSha 2. SCALE 5 CM; (E) Bagovytsya. CoIn (DIAMETER 22 MM) FOR SCALE; (E-F) THIN SECTIONS FROM THE CONGLOMERATE BED IN MAKARIVKA STAINED WITH ALIZARIN RED, SHOWING IDIOMORPHIC DOLOMITE CRYSTALS (UNSTAINED) IN ARGILLACEOUS DOLOMICRITIC MATRIX (OPAQUE, UNSTAINED), AND CALCITIC COMPONENTS (ECHINODERM OSSICLES AND SMALL LITHOCLASTS, STAINED), E - SCALE BAR 100 MM, F $-200 \mathrm{MM}$.

\subsubsection{Grainstone}

The Makarivka Member contains a distinct, $12-20 \mathrm{~cm}$ thick grainstone bed (Figs 5 and 9, Tab. 3). Its boundaries are sharp (Fig. 9A-B); in some places symmetrical ripple marks are visible in the cross-section of the contact between the upper surface of the grainstone bed and the overlying lamination in a heterolith bed (Fig. 9A-B). The lower surface of the bed shows Planolites-like burrows filled with grainstone (Fig. 9C). Grainstone components are partially obliterated by intensive abrasion, but the 
dominant fraction is formed by echinoderm ossicles, bryozoans, ostracods and stromatoporoid fragments. Sorting is moderate, and single larger grains such as complete ostracod valves are aligned parallel to the bedding (Fig. 9D).

\subsubsection{Conglomerate}

The conglomerate bed is laterally exposed in the Makarivka section, where it reaches the thickness of $65 \mathrm{~cm}$ (Fig. 6, Tab. 3). It starts with an erosional boundary scoured into the underlying bed (Fig. 10A-C). The matrix of the conglomerate consists of poorly lithified greenish-gray marl (Fig. 10A) with scattered idiomorphic dolomite crystals (Fig. 10F-G). The clasts are imbricated, and the dominant transport direction was southeast in present-day terms (Fig. 6). The conglomerate bed is normally graded, and the largest clasts in its base are boulder-sized, thrown in some places into the underlying bed (Fig. 10C). The boulders are angular, whereas smaller size fractions show various degrees of rounding and abrasion. They consist of lithoclasts, as well as of chipped and overturned fragments of stromatoporoids, tabulate corals, and bryozoans, which stick out from weathered surfaces (Fig. 10B). Both angular and well-rounded fragments are present, and most show evidence of earlier cementation (e.g., abrasion and cutting through previously cemented structures). Lithoclasts consist predominantly of peloidal grainstones, followed by peloidal packstones and ostracod wacke- to mudstones and rare clasts of crinoidal grainstones (Fig. 11A-D). Lithoclasts generally do not contain typical reef-building organisms such as stromatoporoids or tabulate corals, which are found separately. The conglomerate framework is clastsupported in the lower part of the bed, but becomes mud-supported towards the top of the bed, as the size and amount of clasts decreases. In the two other sections single, well-rounded clasts of stromatoporoids and limestones can be found floating in the laminated argillaceous matrix (Fig. 10D-E). 
A
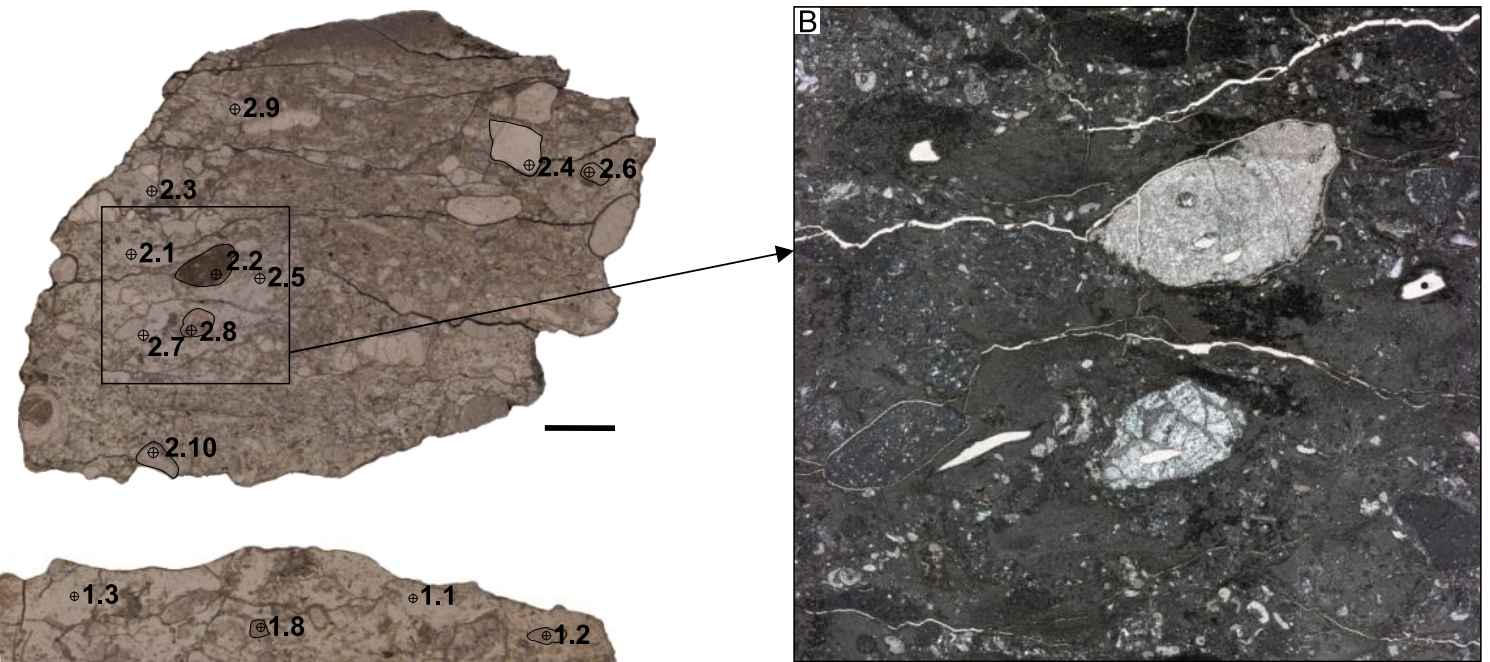

C

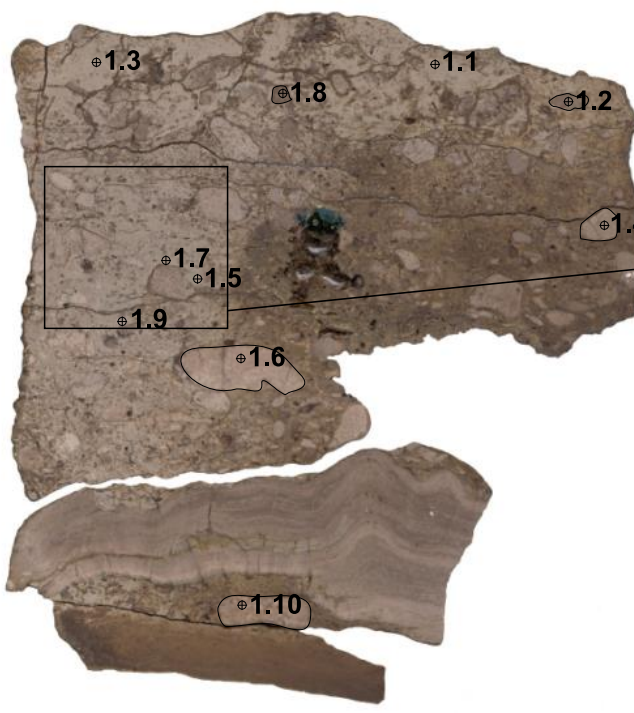

E

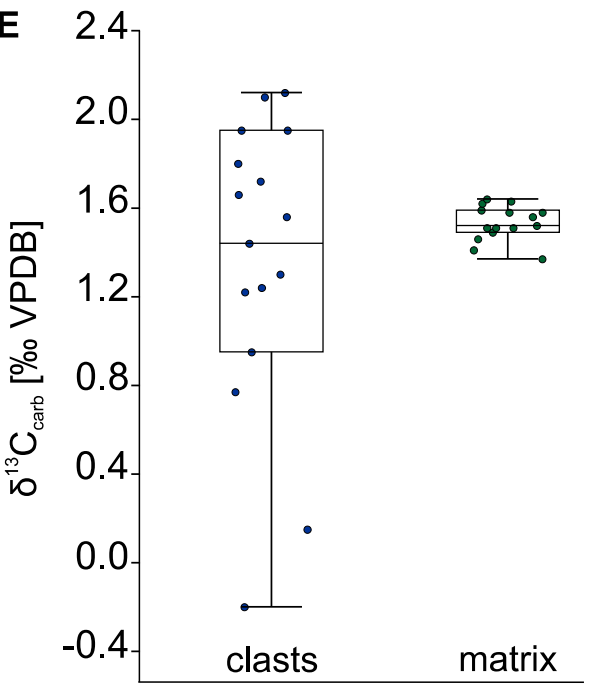

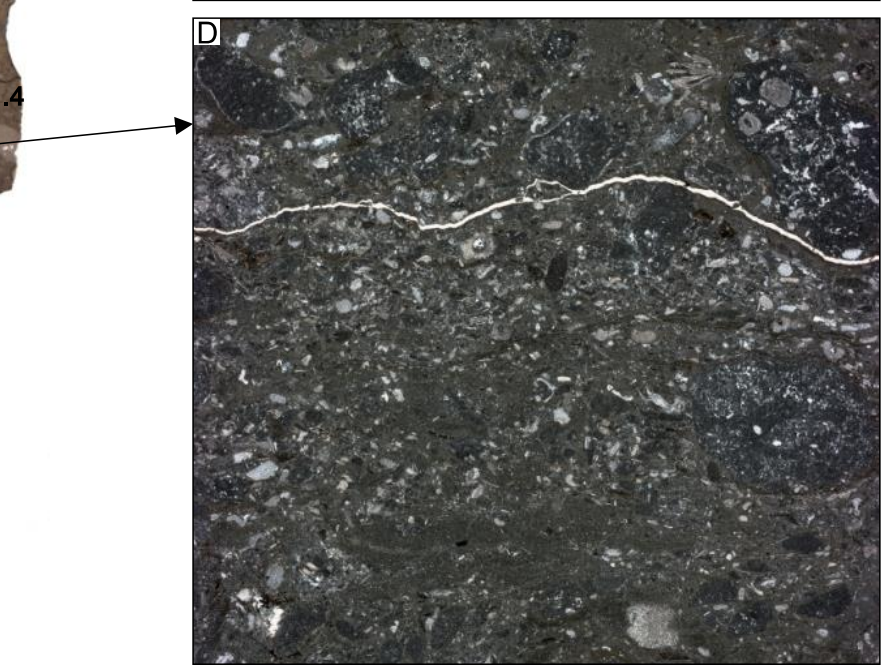

$\mathbf{F}$

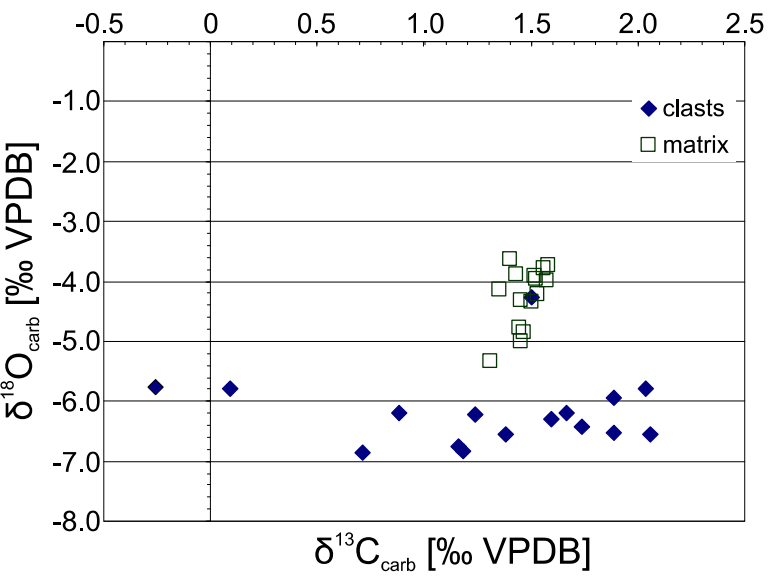

FIGURE 11. DISTRIBUTION OF $\Delta^{13} C_{\text {CARB }}$ VALUES IN THE MATRIX AND CLASTS OF THE CONGLOMERATE BED IN THE Makarivka Member: (A, C) Polished slabs of the Conglomerate Bed, SCAle 1 CM; (B, D) Thin Sections PRODUCED FROM THE SLABS SHOWING THE DOMINANT COMPOSITION OF CLASTS: ABRADED FRAGMENTS OF GRAIN-, PACK- AND WACKESTONES, TABULATE CORALS AND STROMATOPOROIDS, FLOATING IN A MARLY MATRIX; (E) BOX-PLOT OF $\Delta^{13} C_{\text {CARB }}$ VALUES IN THE CLASTS $(N=16)$ AND IN THE MATRIX ( $\left.N=15\right)$; (F) DISTRIBUTION OF $\triangle^{18} \mathrm{O}_{\text {CARB }}$ AND $\triangle^{13} \mathrm{C}_{\text {CARB }}$ VALUES IN THE CLASTS (DIAMONDS) AND MATRIX (SQUARES). 


\subsubsection{Dolomicrite-grainstone heterolith}

The unit is composed of alternating laminae of yellow, argillaceous dolomicrite and crinoidal grainstone (Fig. 12). Boundaries between the two lithologies are sharp, and weathered surfaces of the dolomicrite show low-angle cross-bedding. The proportion between dolomicrite and grainstone varies to a large extent, from current-laminated micritic sediment with scattered thin grainstone lenses, to grainstone with dolomicrite lenses (compare Fig. 12C). The dolomicrite-dominated end-members contain starved ripples (Fig. 12A). The heterolith beds show convolute lamination and small-scale sedimentary diapir structures (Fig. 12C). In Makarivka the laminae are in some places deformed (Fig. 12E), resulting in crumpled, nodular appearance.
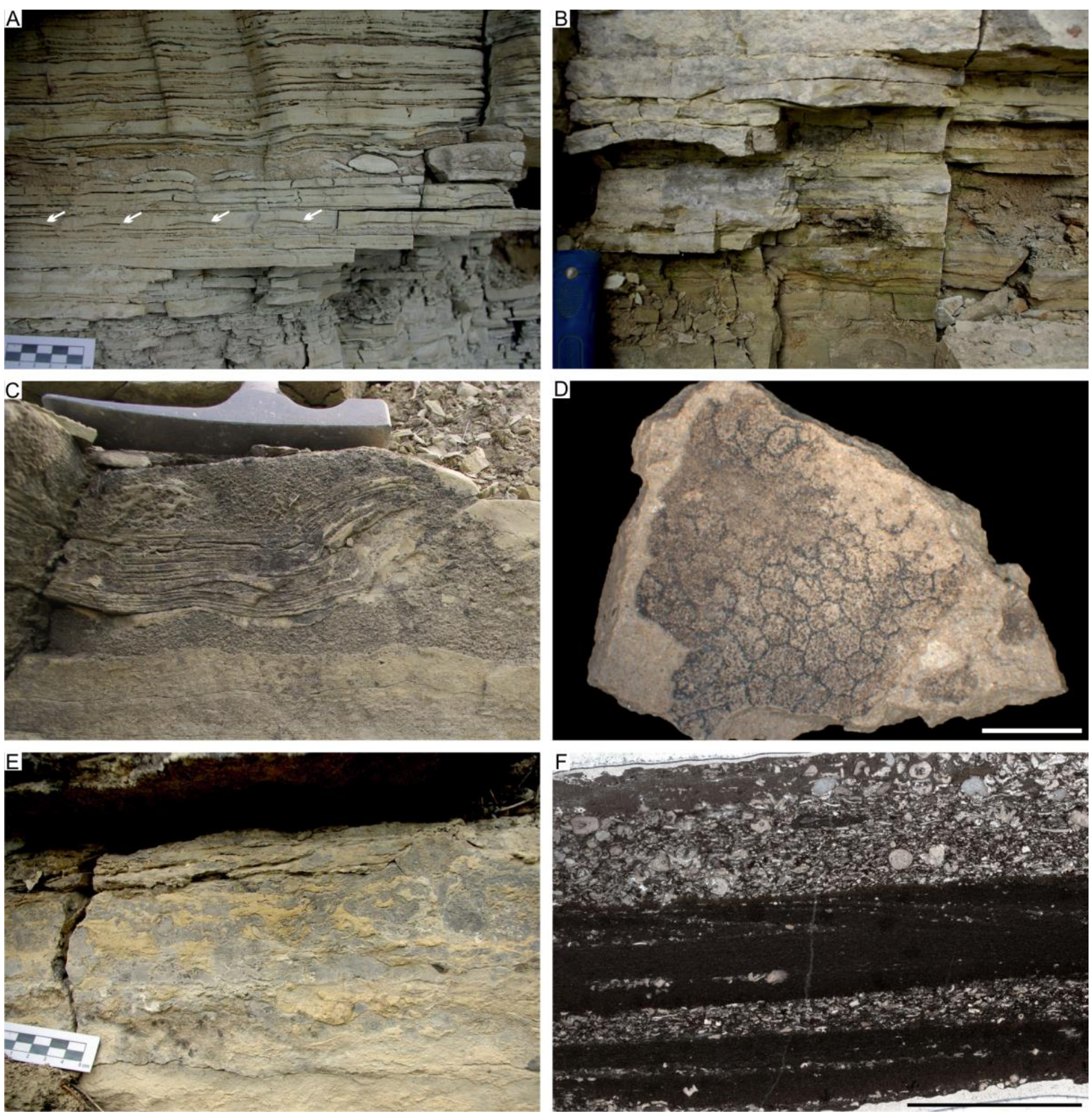
FIGURE 12. GRainstone-MARL heterolith lithology of the Makarivka Member: (A) Marly Rip-up CLASTS AND STARVED RIPPLES (ARROWS). SCALE 5 CM; (B) HETEROLITH IN THE BAGOVYTSYA SECTION; (C) CONVOLUTE LAMINATION. HAMMER HEAD FOR SCALE; (D) CARBONIZED NON-VASCULAR LAND PLANT PARKA DECIPIENS FLEMING, 1831, FROM THE ARGILLACEOUS DOLOMICRITIC COMPONENT. SCALE 2 MM; (E) IRREGULAR SHAPES AND SEDIMENTARY DIAPIRS(?) OF THE MARL AND GRAINSTONE LAMINAE. SCALE 5 CM; (F) MICROFACIES OF THE HETEROLITH: ALTERNATING LAMINAE OF CROSS-BEDDED ARGILLACEOUS DOLOMICRITE AND MODERATELY SORTED CRINOIDAL GRAINSTONE. SCALE 1 CM.

Grainstone in the heterolith is composed predominantly of crinoid ossicles, peloids and ostracods

(Fig. 12F). Sorting varies between different laminae. Grainstone lenses with coarser material contain small (up to $8 \mathrm{~mm}$ ) rounded grainstone and packstone clasts. Most grains have fitted contacts. Dolomicritic laminae contain carbonized compressions of the non-vascular land (terrestrial or freshwater) chlorophyte Parka decipiens Fleming, 1831 (Hemsley, 1989; Abbott et al., 1998; Fig. 12D).

\subsubsection{Carbon and oxygen isotope ratios}

The $\delta^{13} \mathrm{C}_{\text {carb }}$ and $\delta^{18} \mathrm{O}_{\text {carb }}$ values of the conglomerate components were measured in points indicated in Fig. $11 \mathrm{~A}, \mathrm{C}$. Average $\delta^{13} \mathrm{C}_{\text {carb }}$ values of the conglomerate matrix and the clasts are similar: $1.5 \%$ and 1.3\%o respectively (Tab. 1, Fig. 11E-F), but in the matrix they show very little scatter (standard deviation $0.1 \%$, range $1.3 \%$ to $1.6 \%$ ), whereas the clasts exhibit extremely variable values (standard deviation $0.7 \%$, range $-0.3 \%$ to $2.1 \%$ ). The average of $\delta^{18} \mathrm{O}_{\text {carb }}$ values in clasts equals $-6.2 \%$ (standard deviation $0.6 \%$ ), and $-4.3 \%$ (standard deviation $0.5 \%$ ) in the matrix. A summary of $\delta^{13} \mathrm{C}_{\text {carb }}$ and $\delta^{18} \mathrm{O}_{\text {carb }}$ value range within the Makarivka Member and in adjacent beds is given in Table 4. 


\section{Interpretation and discussion}

\subsection{Evidence for the Mechanism of Deposition of the Makarivka Member}

The Makarivka Member represents a succession of beds bounded by erosional surfaces, and composed of allochthonous material characterized by $\delta^{13} \mathrm{C}_{\text {carb }}$ values corresponding to either a broad temporal or spatial scale. The following mechanisms of deposition are discussed below: redeposition of subtidal material by a hurricane or a tsunami, transport of clasts from an uplifted area located landward to the site of deposition, and mixing and reworking of clasts on a transgressive surface. These possibilities are compared below with observations on the sequence stratigraphic position of the Makarivka Member, the direction of clast transport therein, and the presence of sedimentary structures characteristic of storm- and tsunami-generated deposits in Recent settings.

\subsubsection{Sequence stratigraphy}

The upper part of the Muksha Formation records progradation through gradual apppearance of oncoidal limestone intercalations in the calcareous mudstone (Jarochowska et al., 2014). In the uppermost part, oncoidal limestones are either thick-bedded (Makarivka) or contain patch reefs. Both lithologies of the Muksha Formation are abruptly truncated by the overlying Ustya Formation. The contact between Muksha and Ustya formations can be correlated with a widespread upper Homerian sequence boundary recorded in the Baltic Basin (Calner and Jeppsson, 2003), in the Anglo-Welsh Basin (Ray et al., 2010; 2013), and in eastern US (McLaughlin et al., 2008; Brett et al., 2012a; Brett et al., 2012b). In Podolia, the Homerian outcrops are distributed approximately along the depositional strike, and their basinward equivalents located westward of the study area are covered with upper Silurian and younger strata. The depth of erosion associated with the Muksha-Ustya hiatus is therefore not known. In coeval sections located northwest of Podolia in the Baltic Basin, representing open shelf facies, the interval between the two peaks of the Mulde CIE may be as thick as 20 m (Bartoszyce IG1 core, Porębska et al. 2004; Hunninge1 core, Calner et al., 2006).

As the Makarivka Member was deposited shortly above this sequence boundary, a possible origin of the polymictic conglomerate in Makarivka Member as a transgressive lag was considered. This possibility is ruled out based on the fact that the conglomerate cuts erosionally into the the tidal flat established above the sequence boundary between the Muksha and Ustya formations. The deposition of 
the conglomerate was preceded by at least two minor episodes of shoreward transport of crinoidal material from the subtidal zone (Fig. 6) into the intertidal deposits. Erosional lower and upper boundaries between the grainstone beds and the surrounding intertidal lithology, as well as their limited, laterally variable extent, indicate that they represented momentary accumulation rather than small-scale sea-level oscillations, in which case they would occur as bedsets within laterally traceable parasequences. Clast reworking at a transgressive boundary and ravinement surface can be also excluded based on the distal appearance of the Makarivka Member, characterized by sparse subtidal extraclasts floating in the micritic matrix of the intertidal laminite (Fig. 10D-E), which otherwise bears no trace of ravinement scouring.

\subsubsection{Direction of transport}

The ostracod wacke- and packstone, crinoidal grainstone, and individual stromatoporoids, tabulates and bryozoans forming the conglomerate clasts, as well as the crinoid ossicles forming grainstone laminae of the heterolith in the Makarivka Member are exotic to the tidal flat. The chaotic mixture of subtidal lithologies could be the product of transport by flood from an uplifted area located landward, but the south-eastward inclination of clasts in the conglomerate bed, indicating landward transport with respect to the paleo-seashore (Fig. 6) and the presence of bioclasts (stromatoporoids and tabulate corals) derived from the sea-floor preclude this possibility. Also, as there are no other fluvial sediments recorded in the Ustya Formation, the potential flooding stream deposits would be expected to have a limited lateral range, whereas the (at least) kilometer-scale distribution of the Makarivka Member indicates that the allochthonous material was transported by flow over a large area. Due to the lack of mapping studies on the subsurface Wenlock in Podolia the absolute transport distance is difficult to constrain, but the stromatoporoid-coral patch reefs are estimated to have been located a few tens of kilometers seaward (west in present-day directions; Fig. 1).

\subsubsection{Sedimentary structures and comparison with modern analogues} Identification of tsunami deposits in the geologic record and, in particular, the features distinguishing them from storm deposits, have been discussed by many authors (e.g., Dawson and Shi, 2000; Pratt, 2001; 2002; Nott, 2003; Dawson and Stewart, 2007; Kortekaas and Dawson, 2007; Morton et al., 2007; Pratt and Bordonaro, 2007). Simple criteria for identifying a tsunamite do not exist, because the composition of the deposit is controlled by sediment source (Morton et al., 2007). Similarly, the lateral 
extent of tsunami deposits depends on the local topography; Paleozoic low-gradient epeiric shelves do not have modern analogs where models for tsunami deposition could be developed (Pratt and Bordonaro, 2007).

The Makarivka Member has an internal complexity which can be linked to depositional mechanisms observed in Recent tsunamis (e.g., Kortekaas and Dawson, 2007; Fujiwara and Kamataki, 2008; Goto et al., 2012; Naruse et al., 2012). Contemporary tsunami events show that deposition occurs in a series of alternating episodes of sediment erosion, transport and deposition associated with individual waves (Dawson and Shi, 2000). The periodic changes in current power and direction are reflected in the vertical grain-size distribution and sediment composition, although older deposits are often eroded by subsequent waves or the backwash flow (Fujiwara and Kamataki, 2008). The tidal deposits accreted through in situ precipitation of carbonate in microbial mats and trapping detrital sediment, resulting in a nearly featureless tidal flat with little local topographic variations that could generate turbulences in the run-up tsunami waves. Low-relief settings are prone to develop lower velocities of the backwash flow (Morton et al., 2007), which might have contributed to the preservation of the Makarivka Member. Tidal flats in the Silurian of Podolia likely stretched over the distance of tens to hundreds(?) of kilometers (Einasto et al., 1986; Skompski et al., 2008). As tsunami waves are typically free of much suspended sediment at the moment of their generation in the water column until they reach the coastal zone, seabottom elevations such as reefs and shoals are the expected sediment donors (Ward, 2011). Sea level recessions between consecutive tsunami waves can reach hundreds of meters in horizontal length, exposing a broad zone of shoreface sediments which provide material for erosion and emplacement (Liu et al., 2005; Morton et al., 2007).

The tsunamite succession of the Makarivka Member and inferred current direction and velocities are summarized in Figure 13. The essential tsunami deposit consists of the conglomerate bed and the heterolith unit (Figs 5, 6 and 13). Poor sorting and the presence of angular, outsized clasts in the conglomerate indicate short-term, high-energy transport (Fig. 10). The deposition of the conglomerate would correspond to the strongest landward-directed current in the run-up phase. This bed continues in its more distal facies at the distance of at least $4 \mathrm{~km}$ (Bagovytsya). The overlying heterolith unit reflects 
alternating high-density landward currents laden with crinoidal material, and stagnant intervals allowing the mud and chlorophyte debris to settle from suspension into laminated sediments. In storm deposits internal mud lamination is usually absent as a result of persistent high velocity and nearly unidirectional flow (Morton et al., 2007). Such repeated turnover of paleocurrents results from cyclic occurrence of upand return flows, which is possible due to long wave periods (Dawson and Stewart, 2007; Fujiwara and Kamataki, 2007; 2008). Between the passages of subsequent waves, quiescent periods allow finer grained size fractions to settle. The moment the run-up wave reaches its maximum inundation height and changes direction, turning into a backwash current, a momentary stillstand is produced, leading to deposition of coarser material, while silt and clay remains suspended (Dawson and Stewart, 2007). This oscillatory flow is reflected in the saw-toothed grain-size distribution of the heterolithic unit and corresponds to the final stage of the tsunami characterized by a slow decay of the wave energy (Fujiwara and Kamataki, 2007; 2008). This might be indicated by the presence of starved ripples (Fig. 12A), which are considered to be formed by sediment-free water reworking sediment layers deposited earlier, and thus reflect deficiency at least in the sand fraction (Shanmugam et al., 1993; Stanley, 1993).

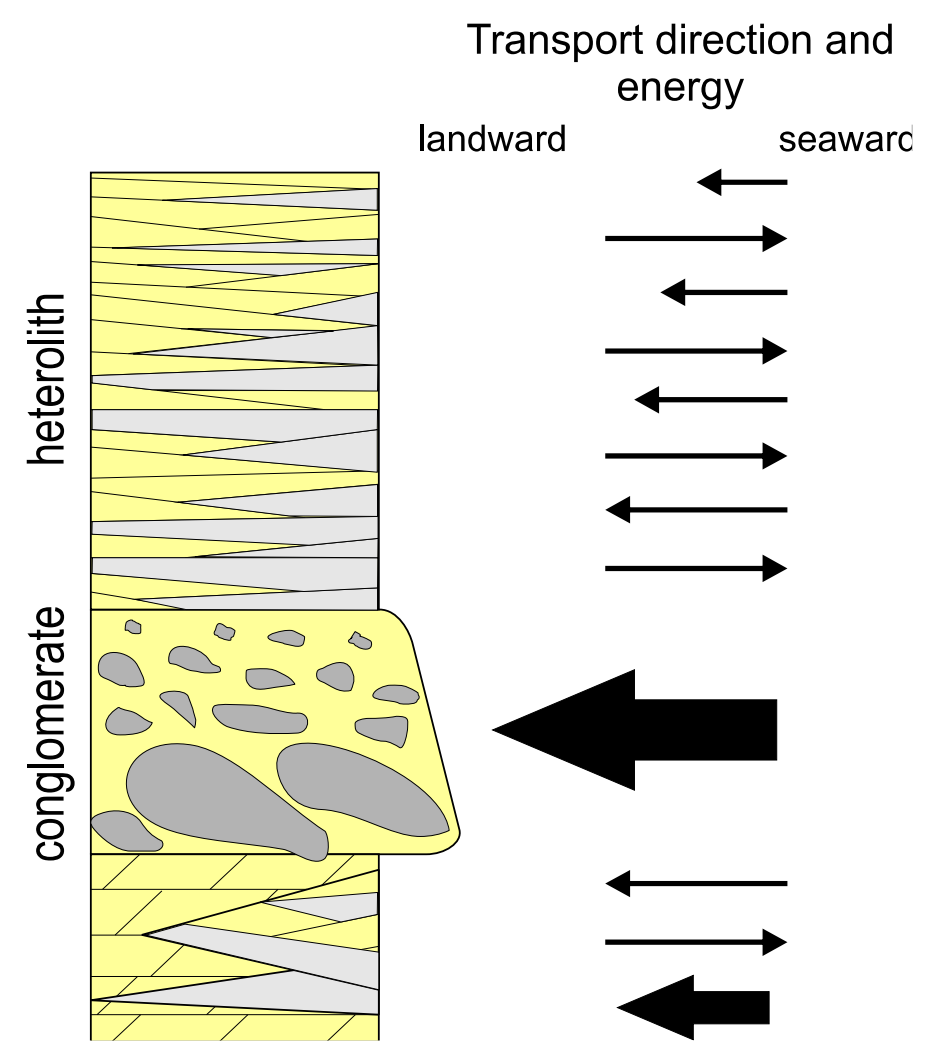


It is not clear whether the grainstone and heterolith beds underlying the conglomerate unit (Figs 5 and 6) have the same tsunami origin. The thickness of the dolomicrites of the Ustya Formation, which display normal bedding and no evidence of transport or reworking (except for a single extraclast in Fig. $8 \mathrm{~A})$, suggest that the two preceding episodes of high-energy shoreward transport were separated by long periods of background sedimentation in the tidal flat. It is most plausible that they reflect earlier tsunami or storm episodes, which had either lower wave energies, that did not lead to emplacement of bouldersized clasts, or had been more extensively eroded. In terms of lithostratigraphy, the grainstone and heterolith beds are distinct from the dominant lithology of the Ustya Formation and petrographically indistiguishable from the main tsunamite unit; they are therefore included in the Makarivka Member.

\subsection{Mechanism of Tsunami Generation}

Tsunami deposits are probably underrecognized in the geologic record, and only a fraction of tsunamis actually occurring has any preservation potential (Dawson and Stewart, 2007). The Baltic Basin, the depositional setting of the strata examined in the present study (Fig. 1), developed during the Silurian into the Caledonian foreland basin. Podolia was at that time close to the front of subduction of the Baltic plate under the Avalonian plate, resulting from the closure of the Tornquist Ocean (Kozłowski et al., 2004; Cocks and Torsvik, 2005; Nawrocki and Poprawa, 2006). Such a setting is favorable for generation of subduction-zone earthquakes, which are the most common triggers of transoceanic tsunamis (Dawson and Stewart, 2007; Ward, 2011). There are, however, no reports of any seismic activity in the coeval strata in the entire basin. Based on combined carbon isotope trends and conodont data, the Wenlock/Ludlow boundary, which falls within the Ustya Formation (Fig. 3), is represented by a complex emersion and ravinement surface in Gotland (Eriksson, 2004). From the corresponding time slice, no sedimentological observations of high-energy depositional events have been reported in deeper-water settings of the Baltic Basin (subsurface Poland and the Baltic Sea).

The Makarivka Member contains sedimentary structures potentially produced by seismic activity. These include cuneiform cracks (Fig. 9C), which could be interpreted as syneresis cracks. Such cracks have been proposed by Pratt (1998) to be indicative of earthquake-induced dewatering. It has, however, been 
recently shown by Harazim et al. (2013) that such cracks may actually be products of intrastratal shrinkage of microbial mats without the prerequisite of seismic deformation. The checkerboard-like cleavage confined to the dolomite in the lower part of the Ustya Formation (Fig. 8B) resembles seismogenic autoclastic breccia discussed by Montenat et al. (2007), which could be generated in a similar manner to the convolute lamination, small-scale diapir structures (Fig. 12C), and crumpled heterolith beds showing internal pinching and sinking structures (Fig. 12E). Such structures are often reported in earthquake-associated deposits (e.g., Shiki and Yamazaki, 1996; McLaughlin and Brett, 2004; Montenat et al., 2007), but they may equally form due to the inherent instability at contacts of sediments with varying density as a result of their thixotropic nature. The deformation may be triggered by multiple mechanisms, such as overpressuring by water or sediment load. McLaughlin and Brett (2004) have applied a parsimonious criterion of the lateral coverage to distinguish between soft-sediment deformations generated by local factors from those due to earthquakes. As long as there is no indication for at least regional extent of such deformation in the Makarivka Member, they cannot be taken as a sufficient support for a seismogenic origin of the tsunami. In the lack of any evidence for bolide impacts in this time slice, a slide-generated tsunami cannot be excluded (Ward, 2001). Particularly submarine slides have only recently been shown to be an important mechanism of tsunami generation, for which hardly any geological record is known (Tappin, 2010). Such a mechanism might explain the presumably restrained lateral range of the tsunamite (Dawson and Stewart, 2007).

\subsection{Temporal versus spatial mixing in the tsunamite and its implications for stratigraphy} The large proportion of matrix distinguishes the conglomerate bed of the Makarivka Member from siliciclastic tsunami deposits, which typically are well winnowed as a result of unidirectional currents resulting from the long wavelengths of the run-up (Fujiwara and Kamataki, 2007; 2008). Furthermore, the matrix shows homogenous $\delta^{13} C_{\text {carb }}$ values compared to the high variability in the lithoclasts, but the average in both groups is nearly equal (Fig. 11E). This points to a possibility that the matrix of the conglomerate is, to a large extent, a product of crushing and abrasion of carbonate lithoclasts. The systematic offset in $\delta^{18} \mathrm{O}_{\text {carb }}$ values (1.9\% on average) indicates that the clasts and the matrix belong to two diagenetic pools. The higher content of dolomite in the matrix (Figs 10E-F) may be the cause of its consistently heavier ${ }^{18} \mathrm{O}_{\text {carb }}$ values as a result of abiogenic dolomite fractionation (Fritz and Smith, 1970; 
McKenzie, 1981). It may also be explained by the contribution of cements (Dickson and Coleman, 1980;

Marshall, 1992; Metzger and Fike, 2013), which would be volumetrically more important in the clasts than in the micritic, poorly lithified matrix (compare Fig. 10A). The contribution of sediment generated in situ on the Ustya tidal flat to the matrix composition might additionally affect the $\delta^{18} \mathrm{O}_{\text {carb }}$ values by contributing primary microcrystalline microbial dolomite, which could not be differentiated from clay in staining with Alizarin red.

Two hypotheses are considered to explain the relationships between the clasts and the matrix: 1) time averaging of the isotope signatures caused by exhumation and redeposition of older material; 2) extensive spatial mixing of contemporaneous sediments characterized by environmentally- or petrographically-specific primary isotope signal or different diagenetic potential (Metzger and Fike, 2013).

\subsubsection{Time averaging}

The extent of time averaging in a tsunami deposit has been reported in a unique study by Fujiwara et al. (2004), who measured ${ }^{14} \mathrm{C}$ ages of molluscan shells in two tsunami deposits, and observed that most shells were exotic to the site of deposition, but that their ages fell within the interval of 50-600 years before the calculated age of the tsunamites. The oldest shells emplaced in the deposits did not exceed 1800 years, which is comparable to the degree of temporal mixing in typical marine bioclastic deposits (Kidwell et al., 2005; Kowalewski and Bambach, 2008). This indicates that tsunamis produce lateral sedimentological mixing across large distances and facies belts, but that the degree of reworking of older sediments, as estimated based on mollusk shells, is not necessarily high.

In the Makarivka Member, $\delta^{13} C_{\text {carb }}$ values from the matrix of the conglomerate and mudstone component of the heterolith unit show homogenized values across their stratigraphic range, i.e. the values vary between $1.2 \%$ and 1.9\% in Makarivka (Tabs 2 and 4) and 1.3\%o to 1.5\% in Bagovytsya (Tab. 1 and Jarochowska et al., 2014). Maximal observed clast $\delta^{13} C_{\text {carb }}$ values $(2.0 \%$ and $2.1 \%$ ) lay within the range observed in the background tidal flat deposits underlying the Makarivka tsunamite. Most values deviating from the average are shifted toward lower values, such as close to $1 \%$, which, in the overall $\delta^{13} C_{\text {carb }}$ curve for the Bagovytsya section, are not recorded until $14 \mathrm{~m}$ below the tsunamite horizon (Fig. 5) at the onset of the excursion. The depth of erosion required to exhume lithologies with low $\delta^{13} C_{\text {carb }}$ values 
is difficult to explain using Recent tsunami analogs, which tend to rip off positive structures of the sea bottom, but do not cut deep into the sediment, and generally not into the bedrock (Dawson, 1994; Morton et al., 2007). Onshore boulder accumulations are known to be formed by both hurricanes and tsunamis, but in either case the seafloor erosion only entrains boulders, which need to be already detached prior to the entrainement. For this reason boulder accumulations are most commonly formed in settings where the waves break up against a reef crest, supplying lithic boulder material, or in rocky shoreline environments, where coarse gravel deposits are permanently generated (Felton and Crook, 2003; Nott and Bryant, 2003; Nott, 2004; Paris et al., 2010). Such situation could be expected on a carbonate platform during early transgression, redeposition of such clasts would, however, require erosion deep enough to cut through the deposits of the Ustya Formation and its subtidal counterparts accumulated above the transgressive surface.

\subsubsection{Spatial mixing}

The high proportion of isotopically light values in shoreward-redeposited components (conglomerate clasts and crinoidal material of the heterolith unit) may reflect a lateral decrease of absolute $\delta^{13} C_{\text {carb }}$ values across coeval strata on a transect from the platform centre towards its margin. Similar trends are observed across isochrones with increasing depth or distance from the platform in Recent settings (e.g., Swart and Eberli, 2005; Swart, 2008; Oehlert et al., 2012) and from isolated epicratonic successions in the geologic record (e.g., Immenhauser et al., 2008; LaPorte et al., 2009). Multiple mechanisms have been proposed to explain this gradient, e.g., increased proportions of aragonite exported from the platform (Swart and Eberli, 2005; Swart, 2008), the differential effect of meteoric diagenesis dependent on relative water depth (Immenhauser et al., 2003), or formation of separate water-masses due to temperature and salinity stratification resulting in isotopically distinct aquafacies (Holmden et al., 1998; Panchuk et al., 2005). A decrease of absolute $\delta^{13} C_{\text {carb }}$ values of the Mulde excursion is generally observed in the Baltic Basin in parallel to increasing paleobathymetry, e.g. from peak values above 4\%o through values below 3\%o (Ventspils and Priekule cores, Kaljo et al., 1998; Grötlingbo-1 core, Calner et al., 2006), below 2\%o (Viduklè core, Martma et al., 2005), down to below 1\%o in open shelf settings (Bartoszyce IG-1 core, Porębska et al., 2004). The gradient of decreasing $\delta^{13} C_{\text {carb }}$ values with distance varies between sections, but, on average, in the above area (East Baltic) it is close to - 
$1 \%$ per $100 \mathrm{~km}$, possibly reflecting the low-relief topography of the ramp. Allochthonous lithoclasts in the Makarivka conglomerate presumably represent settings with contrasting energies (e.g., ostracod wackestones and crinoidal grainstones), but do not contain enough clues on bathymetry, therefore it is not possible to estimate how far they would have been transported. Most clast $\delta^{13} C_{\text {carb }}$ values correspond to $\delta^{13} \mathrm{C}_{\text {carb }}$ values in the strata directly underlying the conglomerate (1.5-2\%。; Fig. 5, Tab. 4) with an admixture of extreme, lower values. The contribution of carbonate clasts transported from further offshore settings and depleted in ${ }^{13} \mathrm{C}$ in the matrix might therefore explain the similar average values in clasts and matrix in the Makarivaka conglomerate. This way an apparent time averaging would be produced due to spatial mixing of $\delta^{13} \mathrm{C}_{\text {carb }}$ values derived from a lateral gradient, detectable at the chemostratigraphic resolution as homogenization of values across the stratigraphic interval represented by the tsunamite bed.

\section{Conclusions}

The Makarivka Member from the Homerian (middle Silurian) of the Dniester River Valley, Ukraine, is a product of tsunami deposition on a carbonate tidal flat, as indicated by the succession of a conglomerate bed with outsized rip-up clasts composed of subtidal material exotic to the flat, and a heterolith unit composed of alternating laminae of argillaceous dolomicrite and grainstone. An earthquake as a mechanism generating the tsunami cannot be excluded, but potential sedimentary structures supporting the seismogenic nature of the tsunami are limited to the studied sections, and have not been reported from coeval sections in the Baltic Basin. The Makarivka Mb. was deposited during an interval of lowering isotopic values of the Mulde positive carbon isotope excursion. The comparison of matrix and lithoclast $\delta^{13} C_{\text {carb }}$ values of the Makarivka tsunamite indicate that clasts appear time-averaged with respect to $\delta^{13} \mathrm{C}$ chemostratigraphic trend, likely as a result of mixing contemporary material entrained from the sea floor with clasts derived from offshore settings, characterized by lower $\delta^{13} C_{\text {carb }}$ values. The time averaging by the tsunami is estimated to be insignificant compared to the rate at which the $\delta^{13} C_{\text {carb }}$ values decrease in the lowering limb of the Mulde excursion, but the comparably higher thickness of the Makarivka Member values results in an apparent slower decay of elevated values. 


\section{Acknowledgments}

This work was supported by the Deutsche Forschungsgemeinschaft (project no. Mu 2352/3). We thank C. E. Brett, L. Ainsaar, P. I. McLaughlin, and A. Immenhauser for suggestions which helped us to improve an earlier version of this manuscript. K. Frisch is acknowledged for help in field and laboratory work, R. Nawrot for assistance in fieldwork and the finding of $P$. decipiens, B. Leipner-Mata for help in producing thin sections, M. Joachimski and D. Lutz for carbon and oxygen isotope analyses, and $\mathrm{O}$. Lehnert, R. Nawrot, W. Kozłowski, and M. López Correa for discussions. This paper is a contribution to the International Geoscience Programme (IGCP) Project 591 - The Early to Middle Palaeozoic Revolution.

\section{Data availability statement}

Tables 1-4 and high-resolution figures are available at https://osf.io/mu9aq/ under the CC-By Attribution 4.0 International license.

\section{References}

Abbott, G.D., Ewbank, G., Edwards, D., Wang, G.-Y., 1998. Molecular characterization of some enigmatic Lower Devonian fossils. Geochimica et Cosmochimica Acta, 62(8): 1407-1418.

Brett, C.E., McLaughlin, P.I., Schramm, T.J., Sullivan, N.B., Thomka, J.R., 2012a. Middle Paleozoic sequence stratigraphy and paleontology of the Cincinnati Arch: part 1. Central Kentucky and southern Ohio. University of Cincinnati, Cincinnati, 143 pp.

Brett, C.E., Cramer, B.D., Dattilo, B.F., McLaughlin, P.I., Schramm, T.J., Thomka, J.R., 2012b. Middle Paleozoic sequence stratigraphy and paleontology of the Cincinnati Arch: part 2. Northern Kentucky and SE Indiana. University of Cincinnati, Cincinnati, 97 pp.

Calner, M., Jeppsson, L., 2003. Carbonate platform evolution and conodont stratigraphy during the middle Silurian Mulde Event, Gotland, Sweden. Geological Magazine, 140(02): 173-203.

Calner, M., Lehnert, O., Jeppsson, L., 2012. New chemostratigraphic data through the Mulde Event interval (Silurian, Wenlock), Gotland, Sweden. GFF, 134(1): 65-67. 
Calner, M., Kozłowska, A., Masiak, M., Schmitz, B., 2006. A shoreline to deep basin correlation chart for the middle Silurian coupled extinction-stable isotopic event. GFF, 128: 79-84.

Cocks, L.R.M., Torsvik, T.H., 2005. Baltica from the late Precambrian to mid-Palaeozoic times: The gain and loss of a terrane's identity. Earth-Science Reviews, 72(1-2): 39-66.

Corfield, R.M., Siveter, D.J., Cartlidge, J.E., McKerrow, W.S., 1992. Carbon isotope excursion near the Wenlock-Ludlow, (Silurian) boundary in the Anglo-Welsh area. Geology, 20(4): 371-374.

Cramer, B.D., Kleffner, M.A., Saltzman, M.R., 2006. The Late Wenlock Mulde positive carbon isotope $\delta^{13} C_{\text {carb }}$ excursion in North America. GFF, 128: 85-90.

Cramer, B.D., Kleffner, M.A., Brett, C.E., McLaughlin, P.I., Jeppsson, L., Munnecke, A., Samtleben, C., 2010a. Paleobiogeography, high-resolution stratigraphy, and the future of Paleozoic biostratigraphy: Fine-scale diachroneity of the Wenlock (Silurian) conodont Kockelella walliseri. Palaeogeography, Palaeoclimatology, Palaeoecology, 294(3-4): 232-241.

Cramer, B.D., Condon, D.J., Söderlund, U., Marshall, C., Worton, G.J., Thomas, A.T., Calner, M., Ray, D.C., Perrier, V., Boomer, I., Patchett, P.J., Jeppsson, L., 2012. U-Pb (zircon) age constraints on the timing and duration of Wenlock (Silurian) paleocommunity collapse and recovery during the "Big Crisis". Geological Society of America Bulletin, 124(11-12): 1841-1857.

Cramer, B.D., Loydell, D.K., Samtleben, C., Munnecke, A., Kaljo, D., Männik, P., Martma, T., Jeppsson, L., Kleffner, M.A., Barrick, J.E., Johnson, C.A., Emsbo, P., Joachimski, M.M., Bickert, T., Saltzman, M.R., 2010b. Testing the limits of Paleozoic chronostratigraphic correlation via high-resolution ( $<500$ k.y.) integrated conodont, graptolite, and carbon isotope $\left(\delta^{13} C_{c a r b}\right)$ biochemostratigraphy across the Llandovery-Wenlock (Silurian) boundary: Is a unified Phanerozoic time scale achievable? Geological Society of America Bulletin, 122(9-10): 1700-1716.

Dawson, A.G., 1994. Geomorphological effects of tsunami run-up and backwash. Geomorphology, 10(14): 83-94.

Dawson, A.G., Shi, S., 2000. Tsunami deposits. Pure and applied geophysics, 157: 875-897. 
Dawson, A.G., Stewart, I., 2007. Tsunami deposits in the geological record. Sedimentary Geology, 200(34): 166-183.

Dickson, J.A.D., Coleman, M.L., 1980. Changes in carbon and oxygen isotope composition during limestone diagenesis. Sedimentology, 27(1): 107-118.

Einasto, P.E., Abushik, A.F., Kaljo, D.L., Koren, T.N., Modzalevskaya, T.L., Nestor, H.E., 1986. Osobiennosti silurskoho osadkonakoplenija i associacji fauny w kraevych bassejnach Pribaltiki i Podolii. In: D.L. Kaljo, E. Klaamann (Eds.), Teoria i opyt ekostratigrafii. Valgus, Tallin, pp. 65-72. (in Russian)

Eriksson, M.J., 2004. Formation and significance of a middle Silurian ravinement surface on Gotland, Sweden. Sedimentary Geology, 170(3-4): 163-175.

Felton, E.A., Crook, K.A.W., 2003. Evaluating the impacts of huge waves on rocky shorelines: an essay review of the book 'Tsunami - The Underrated Hazard'. Marine Geology, 197(1-4): 1-12.

Friedman, G.M., 1959. Identification of carbonate minerals by staining methods. Journal of Sedimentary Research, 29(1): 87-97.

Fritz, P., Smith, D.G.W., 1970. The isotopic composition of secondary dolomites. Geochimica et Cosmochimica Acta, 34(11): 1161-1173.

Frýda, J., Frýdová, B., 2014. First evidence for the Homerian (late Wenlock, Silurian) positive carbon isotope excursion from peri-Gondwana: new data from the Barrandian (Perunica). Bulletin of Geosciences, 89(3): 617-634.

Fujiwara, O., Kamataki, T., 2007. Identification of tsunami deposits considering the tsunami waveform: An example of subaqueous tsunami deposits in Holocene shallow bay on southern Boso Peninsula, Central Japan. Sedimentary Geology, 200(3-4): 295-313.

Fujiwara, O., Kamataki, T., 2008. Tsunami depositional processes reflecting the waveform in a small bay: interpretation from the grain-size distribution and sedimentary structures. In: T. Shiki, Y. Tsuji, K. Minoura, T. Yamazaki (Eds.), Tsunamiites - features and implications. Elsevier, Amsterdam, pp. 133-152. 
Fujiwara, O., Kamataki, T., Masuda, F., 2004. Sedimentological time-averaging and ${ }^{14} \mathrm{C}$ dating of marine shells. Nuclear Instruments and Methods in Physics Research Section B: Beam Interactions with Materials and Atoms, 223-224(0): 540-544.

Goto, K., Sugawara, D., Ikema, S., Miyagi, T., 2012. Sedimentary processes associated with sand and boulder deposits formed by the 2011 Tohoku-oki tsunami at Sabusawa Island, Japan. Sedimentary Geology, 282(0): 188-198.

Hammer, Ø., Harper, D.A.T., Ryan, P.D., 2001. PAST: Paleontological statistics software package for education and data analysis. Palaeontologia Electronica, 4(1): 9.

Harazim, D., Callow, R.H.T., Mcllroy, D., 2013. Microbial mats implicated in the generation of intrastratal shrinkage ('synaeresis') cracks. Sedimentology, 60(7): 1621-1638.

Hemsley, A.R., 1989. The ultrastructure of the spores of the Devonian plant Parka decipiens. Annals of Botany, 64(3): 359-367.

Holmden, C., Creaser, R.A., Muehlenbachs, K., Leslie, S.A., Bergström, S.M., 1998. Isotopic evidence for geochemical decoupling between ancient epeiric seas and bordering oceans: Implications for secular curves. Geology, 26(6): 567-570.

Immenhauser, A., Holmden, C., Patterson, W.P., 2008. Interpreting the carbon-isotope record of ancient shallow epeiric seas: lessons from the Recent. In: B.R. Pratt, C. Holmden (Eds.), Dynamics of Epeiric Seas. Geological Association of Canada, Special Publication, pp. 137-174.

Immenhauser, A., Della Porta, G., Kenter, J.A.M., Bahamonde, J.R., 2003. An alternative model for positive shifts in shallow-marine carbonate $\delta^{13} \mathrm{C}$ and $\delta^{18} \mathrm{O}$. Sedimentology, 50(5): 953-959.

Jarochowska, E., Kozłowski, W., 2014. Facies development and sequence stratigraphy of the Ludfordian (Upper Silurian) deposits in the Zbruch River Valley, Podolia, western Ukraine: local facies overprint on the $\delta^{13} C_{\text {carb }}$ record of a global stable carbon isotope excursion. Facies, 60(1): 347369. 
Jarochowska, E., Munnecke, A. 2021. Supporting data for Silurian carbonate high-energy deposits of potential tsunami origin: distinguishing lateral redeposition and time averaging using carbon isotope chemostratigraphy. Retrieved from osf.io/mu9aq, DOI 10.17605/OSF.IO/MU9AQ

Jarochowska, E., Munnecke, A., Kozłowski, W., 2014. An unusual microbial-rostroconch assemblage from the Mulde Event (Homerian, middle Silurian) in Podolia, Western Ukraine. GFF, 136(1): 120-124.

Jeppsson, L., Calner, M., 2003. The Silurian Mulde Event and a scenario for secundo-secundo events. Transactions of the Royal Society of Edinburgh: Earth Sciences, 93: 135-154.

Kaljo, D., Martma, T., 2006. Application of carbon isotope stratigraphy to dating the Baltic Silurian rocks. GFF, 128(2): 123-129.

Kaljo, D., Kiipli, T., Martma, T., 1997. Carbon isotope event markers through the Wenlock-Pridoli sequence at Ohesaare (Estonia) and Priekule (Latvia). Palaeogeography, Palaeoclimatology, Palaeoecology, 132(1-4): 211-223.

Kaljo, D.L., Kiipli, T., Martma, T., 1998. Correlation of carbon isotope events and environmental cyclicity in the East Baltic Silurian. In: L. Landing, M.E. Johnson (Eds.), Silurian cycles-linkages of dynamic stratigraphy with atmospheric, oceanic and tectonic changes. New York State Museum Bulletin. New York State Museum, pp. 297-312.

Kaljo, D.L., Grytsenko, V.P., Martma, T., Mõtus, M.A., 2007. Three global carbon isotope shifts in the Silurian of Podolia (Ukraine): stratigraphical implications. Estonian Journal of Earth Sciences, 56(4): 205-220.

Kidwell, S.M., Best, M.M.R., Kaufman, D.S., 2005. Taphonomic trade-offs in tropical marine death assemblages: Differential time averaging, shell loss, and probable bias in siliciclastic vs. carbonate facies. Geology, 33(9): 729-732.

Kortekaas, S., Dawson, A.G., 2007. Distinguishing tsunami and storm deposits: An example from Martinhal, SW Portugal. Sedimentary Geology, 200(3-4): 208-221. 
Kowalewski, M., 1996. Time-averaging, overcompleteness, and the geological record. The Journal of Geology, 104(3): 317-326.

Kowalewski, M., Rimstidt, J.D., 2003. Average lifetime and age spectra of detrital grains: toward a unifying theory of sedimentary particles. The Journal of Geology, 111(4): 427-439.

Kowalewski, M., Bambach, R.K., 2008. The limits of paleontological resolution. In: P.J. Harries (Ed.), Approaches in High-Resolution Stratigraphic Paleontology. Kluwer Academic/Plenum Publishers, New York, pp. 1-48.

Kozłowski, W., Domańska, J., Nawrocki, J., Pecskay, Z., 2004. The provenance of the upper Silurian greywackes from the Holy Cross Mountains (central Poland). Mineralogical Society of Poland Special Papers, 24: 251-254.

LaPorte, D.F., Holmden, C., Patterson, W.P., Loxton, J.D., Melchin, M.J., Mitchell, C.E., Finney, S.C., Sheets, H.D., 2009. Local and global perspectives on carbon and nitrogen cycling during the Hirnantian glaciation. Palaeogeography, Palaeoclimatology, Palaeoecology, 276(1-4): 182-195.

Liu, P.L.-F., Lynett, P., Fernando, H., Jaffe, B.E., Fritz, H., Higman, B., Morton, R., Goff, J., Synolakis, C., 2005. Observations by the International Tsunami Survey Team in Sri Lanka. Science, 308(5728): 1595.

Marshall, C., Thomas, A.T., Boomer, I., Ray, D.C., 2012. High resolution $\delta^{13} C_{\text {carb }}$ stratigraphy of the Homerian (Wenlock) of the English Midlands and Wenlock Edge. Bulletin of Geosciences, 87(4): $669-679$.

Marshall, J.D., 1992. Climatic and oceanographic isotopic signals from the carbonate rock record and their preservation. Geological Magazine, 129(2): 143-160.

Martma, T., Brazauskas, A., Kaljo, D., Kaminskas, D., Musteikis, P., 2005. The Wenlock-Ludlow carbon isotope trend in the Vidukle core, Lithuania, and its relations with oceanic events. Geological Quarterly, 49(2): 223-234. 
McKenzie, J.A., 1981. Holocene Dolomitization of Calcium Carbonate Sediments from the Coastal Sabkhas of Abu Dhabi, U.A.E.: A Stable Isotope Study. The Journal of Geology, 89(2): 185-198.

McLaughlin, P.I., Brett, C.E., 2004. Eustatic and tectonic control on the distribution of marine seismites: examples from the Upper Ordovician of Kentucky, USA. Sedimentary Geology, 168(3-4): 165-192.

McLaughlin, P.I., Cramer, B.D., Brett, C.E., Kleffner, M.A., 2008. Silurian high-resolution stratigraphy on the Cincinnati Arch: Progress on recalibrating the layer-cake. In: A.H. Maria, R.C. Counts (Eds.), From the Cincinnati Arch to the Illinois Basin: Geological field excursions along the Ohio River Valley. Geological Society of America Field Guide. Geological Society of America, pp. 119-180.

Metzger, J.G., Fike, D.A., 2013. Techniques for assessing spatial heterogeneity of carbonate $\delta^{13} \mathrm{C}$ values: Implications for craton-wide isotope gradients. Sedimentology, 60(6): 1405-1431.

Montenat, C., Barrier, P., Ott d’Estevou, P., Hibsch, C., 2007. Seismites: An attempt at critical analysis and classification. Sedimentary Geology, 196(1-4): 5-30.

Morton, R.A., Gelfenbaum, G., Jaffe, B.E., 2007. Physical criteria for distinguishing sandy tsunami and storm deposits using modern examples. Sedimentary Geology, 200(3-4): 184-207.

Naruse, H., Arai, K., Matsumoto, D., Takahashi, H., Yamashita, S., Tanaka, G., Murayama, M., 2012. Sedimentary features observed in the tsunami deposits at Rikuzentakata City. Sedimentary Geology, 282(0): 199-215.

Nawrocki, J., Poprawa, P., 2006. Development of Trans-European Suture Zone in Poland: from Ediacaran rifting to Early Palaeozoic accretion. Geological Quarterly, 50(1): 59-76.

Nikiforova, O.I., Predtechenskij, N.N., Abushik, A.F., Ignatovich, M.M., Modzalevskaya, T.L., Berger, A.Y., Novoselova, L.S., Burkov, Y.K., 1972. Opornyj razrez Silura i Nizhnego Devona Podolii. Nauka, Leningrad, 262 pp. (in Russian)

Noble, P.J., Zimmerman, M.K., Holmden, C., Lenz, A.C., 2005. Early Silurian (Wenlockian) $\delta^{13}$ C profiles from the Cape Phillips Formation, Arctic Canada and their relation to biotic events. Canadian Journal of Earth Sciences, 42(8): 1419-1430. 
Noble, P.J., Lenz, A.C., Holmden, C., Masiak, M., Zimmerman, M.K., Poulson, S.R., Kozłowska, A., 2012. Isotope geochemistry and plankton response to the Ireviken (earliest Wenlock) and Cyrtograptus Iundgreni extinction events, Cape Phillips Formation, Arctic Canada. In: J.A. Talent (Ed.), Earth and Life. International Year of Planet Earth. Springer Netherlands, pp. 631-652.

Nott, J., 2003. Tsunami or storm waves? Determining the origin of a spectacular field of wave emplaced boulders using numerical storm surge and wave models and hydrodynamic transport equations. Journal of Coastal Research, 19(2): 348-356.

Nott, J., 2004. The tsunami hypothesis-comparisons of the field evidence against the effects, on the Western Australian coast, of some of the most powerful storms on Earth. Marine Geology, 208(1): 1-12.

Nott, J., Bryant, E., 2003. Extreme marine inundations (tsunamis?) of coastal Western Australia. The Journal of Geology, 111(6): 691-706.

Oehlert, A.M., Lamb-Wozniak, K.A., Devlin, Q.B., Mackenzie, G.J., Reijmer, J.J.G., Swart, P.K., 2012. The stable carbon isotopic composition of organic material in platform derived sediments: implications for reconstructing the global carbon cycle. Sedimentology, 59(1): 319-335.

Panchuk, K.M., Holmden, C., Kump, L.R., 2005. Sensitivity of the epeiric sea carbon isotope record to localscale carbon cycle processes: Tales from the Mohawkian Sea. Palaeogeography, Palaeoclimatology, Palaeoecology, 228(3-4): 320-337.

Paris, R., Fournier, J., Poizot, E., Etienne, S., Morin, J., Lavigne, F., Wassmer, P., 2010. Boulder and fine sediment transport and deposition by the 2004 tsunami in Lhok Nga (western Banda Aceh, Sumatra, Indonesia): A coupled offshore-onshore model. Marine Geology, 268(1-4): 43-54.

Poprawa, P., Šliaupa, S., Stephenson, R., Lazauskienè, J., 1999. Late Vendian-Early Palæozoic tectonic evolution of the Baltic Basin: regional tectonic implications from subsidence analysis. Tectonophysics, 314(1-3): 219-239. 
Porębska, E., Kozłowska-Dawidziuk, A., Masiak, M., 2004. The lundgreni event in the Silurian of the East European Platform, Poland. Palaeogeography, Palaeoclimatology, Palaeoecology, 213(3-4): 271294.

Pratt, B.R., 1998. Syneresis cracks: subaqueous shrinkage in argillaceous sediments caused by earthquakeinduced dewatering. Sedimentary Geology, 117(1-2): 1-10.

Pratt, B.R., 2001. Oceanography, bathymetry and syndepositional tectonics of a Precambrian intracratonic basin: integrating sediments, storms, earthquakes and tsunamis in the Belt Supergroup (Helena Formation, ca. $1.45 \mathrm{Ga}$ ), western North America. Sedimentary Geology, 141-142(0): 371-394.

Pratt, B.R., 2002. Storms versus tsunamis: Dynamic interplay of sedimentary, diagenetic, and tectonic processes in the Cambrian of Montana. Geology, 30(5): 423-426.

Pratt, B.R., Bordonaro, O.L., 2007. Tsunamis in a stormy sea: middle Cambrian inner-shelf limestones of Western Argentina. Journal of Sedimentary Research, 77(4): 256-262.

Racki, G., Baliński, A., Wrona, R., Małkowski, K., Drygant, D., Szaniawski, H., 2012. Faunal dynamics across the Silurian-Devonian positive isotope excursions $\left(\delta^{13} \mathrm{C}, \delta^{18} \mathrm{O}\right)$ in Podolia, Ukraine: comparative analysis of the Ireviken and Klonk Events. Acta Palaeontologica Polonica, 57(4): 795-832.

Ray, D.C., Brett, C.E., Thomas, A.T., Collings, A.V.J., 2010. Late Wenlock sequence stratigraphy in central England. Geological Magazine, 147(01): 123-144.

Ray, D.C., Richards, T.D., Brett, C.E., Morton, A., Brown, A.M., 2013. Late Wenlock sequence and bentonite stratigraphy in the Malvern, Suckley and Abberley Hills, England. Palaeogeography, Palaeoclimatology, Palaeoecology, 389(0): 115-127.

Sadler, P.M., 2012. Integrating carbon isotope excursions into automated stratigraphic correlation: an example from the Silurian of Baltica. Bulletin of Geosciences, 87(4): 681-694.

Samtleben, C., Munnecke, A., Bickert, T., 2000. Development of facies and C/O-isotopes in transects through the Ludlow of Gotland: Evidence for global and local influences on a shallow-marine environment. Facies, 43(1): 1-38. 
Shanmugam, G., Spalding, T.D., Rofheart, D.H., 1993. Traction structures in deep-marine, bottom-currentreworked sands in the Pliocene and Pleistocene, Gulf of Mexico. Geology, 21(10): 929-932.

Shiki, T., Yamazaki, T., 1996. Tsunami-induced conglomerates in Miocene upper bathyal deposits, Chita Peninsula, central Japan. Sedimentary Geology, 104(1-4): 175-188.

Skompski, S., Łuczyński, P., Drygant, D.M., Kozłowski, W., 2008. High-energy sedimentary events in lagoonal successions of the Upper Silurian of Podolia, Ukraine. Facies, 54(2): 277-296.

Stanley, D.J., 1993. Model for turbidite-to-contourite continuum and multiple process transport in deep marine settings: examples in the rock record. Sedimentary Geology, 82(1-4): 241-255.

Swart, P.K., 2008. Global synchronous changes in the carbon isotopic composition of carbonate sediments unrelated to changes in the global carbon cycle. Proceedings of the National Academy of Sciences, 105(37): 13741-13745.

Swart, P.K., Eberli, G., 2005. The nature of the $\delta^{13} \mathrm{C}$ of periplatform sediments: Implications for stratigraphy and the global carbon cycle. Sedimentary Geology, 175(1-4): 115-129.

Tappin, D.R., 2010. Submarine mass failures as tsunami sources: their climate control. Philosophical Transactions of the Royal Society A: Mathematical, Physical and Engineering Sciences, 368(1919): 2417-2434.

Tsegelnyuk, P., Grytsenko, V.P., Konstantynenko, L.I., Ishchenko, A.A., Abushik, A.F., Bogoyavlenskaya, O.W., Drygant, D., Zaika-Novatskyj, W.S., Kadlets, N.M., Kyselev, G.N., Sytova, W.A., 1983. The Silurian of Podolia, a guide of the excursion. Naukova Dumka, Kiev, 224 pp. (in Russian)

Ward, S., 2001. Landslide tsunami. Journal of Geophysical Research: Solid Earth, 106(B6): 11201-11215.

Ward, S., 2011. Tsunami. In: H. Gupta (Ed.), Encyclopedia of Solid Earth Geophysics. Encyclopedia of Earth Sciences Series. Springer Netherlands, pp. 1473-1493. 
TABLE 1. $\delta^{18} \mathrm{O}_{\text {carb }}$ and $\delta^{13} \mathrm{C}_{\text {carb }}$ values from lithoclasts and matrix of the conglomerate bed in the Makarivka Member tsunamite (Makarivka, Podolia, Ukraine). The position of the conglomerate is indicated in Fig. 5, and positions of individual sampling points within conglomerate slabs are marked in Fig. 11A, C.

\section{Sample $\quad \delta^{18} O_{\text {carb }}[\% \circ V-P D B] \quad \delta^{13} C_{\text {carb }}[\%$ V-PDB] $\quad$ Type}

1.4

PB1 1112c

0.4

0.2

2.4

1.2

1.8

1.6

1.10

2.10

2.2

0.5

0.3

0.1

2.8

2.6

1.9
$-5.8$

$-5.8$

$-6.9$

$-6.2$

$-6.8$

$-6.8$

$-6.2$

$-6.5$

$-4.3$

$-6.3$

$-6.2$

$-6.4$

$-6.5$

$-5.9$

$-5.8$

$-6.6$

$-5.3$
-0.3 clast

0.1 clast

0.7 clast

0.9 clast

1.2 clast

1.2 clast

1.2 clast

1.4 clast

1.5 clast

1.6 clast

1.7 clast

1.7 clast

1.9 clast

1.9 clast

2.0 clast

2.1 clast

1.3 matrix 
1.7

2.1

2.5

0.9

PB1 1112m

1.3

2.7

1.5

0.7

0.8

1.1

2.3

2.9

0.6
$-4.1$

$-3.6$

$-3.9$

$-4.8$

$-5.0$

$-4.3$

$-4.9$

$-4.3$

$-3.9$

$-4.0$

$-4.2$

$-3.8$

$-4.0$

$-3.7$
1.4 matrix

1.4 matrix

1.4 matrix

1.5 matrix

1.5 matrix

1.5 matrix

1.5 matrix

1.5 matrix

1.5 matrix

1.5 matrix

1.5 matrix

1.6 matrix

1.6 matrix

1.6 matrix 
TABLE 2. $\delta^{18} \mathrm{O}_{\text {carb }}$ and $\delta^{13} \mathrm{C}_{\text {carb }}$ development across a vertical section in Makarivka (Podolia, Ukraine) in the point marked in Fig. 6. Sample positions are expressed in centimetres above the boundary between the Muksha and Ustya formations.

\begin{tabular}{|c|c|c|}
\hline Sample & $\delta^{18} O_{\text {carb }}[\% \circ \mathrm{V}-\mathrm{PDB}]$ & $\delta^{13} C_{\text {carb }}[\% o \mathrm{~V}-\mathrm{PDB}]$ \\
\hline MB 30 & -6.1 & 3.3 \\
\hline MB 46 & -6.0 & 3.2 \\
\hline MB 60 & -5.2 & 3.0 \\
\hline MB 85 & -3.2 & 2.2 \\
\hline MB 100 & -3.6 & 2.5 \\
\hline MB 120 & -2.6 & 1.7 \\
\hline MB 130 & -6.7 & 2.5 \\
\hline MB 140 & -6.6 & 2.2 \\
\hline MB 150 & -5.0 & 1.7 \\
\hline MB 160 & -0.9 & 1.6 \\
\hline MB 170 & -2.9 & 1.8 \\
\hline MB 180 & -3.2 & 2.2 \\
\hline MB 190 & -3.5 & 1.9 \\
\hline MB 200 & -5.0 & 1.5 \\
\hline MB 240 & -6.4 & 1.4 \\
\hline MB 275 & -5.2 & 1.4 \\
\hline MB 290 & -6.6 & 1.6 \\
\hline
\end{tabular}




\begin{tabular}{|c|c|c|}
\hline MB 295 & -6.5 & 1.5 \\
\hline MB 300 & -6.5 & 1.2 \\
\hline MB 310 & -6.4 & 1.3 \\
\hline MB 330 & -6.6 & 1.2 \\
\hline MB 340 & -6.7 & 1.3 \\
\hline MB 350 & -6.2 & 1.4 \\
\hline MB 370 & -5.6 & 1.4 \\
\hline MB 400 & -4.8 & 1.3 \\
\hline MB 420 & -6.2 & 1.6 \\
\hline MB 434 & -6.5 & 0.7 \\
\hline MB 460 & -6.8 & 1.0 \\
\hline MB 480 & -7.4 & 0.9 \\
\hline MB 510 & -7.7 & 0.3 \\
\hline MB 530 & -7.4 & 0.9 \\
\hline
\end{tabular}


TABLE 3. Thickness of the Ustya Formation and individual beds of the Makarivka Member, as exposed in its type locality. Beds are given in stratigraphic order corresponding to Fig. 6.

Min. thickness [m]

16 according to Tsegelnyuk et 24 in Bagovytsya

Ustya Fm.

Upper grainstone

Upper heterolith

Conglomerate

Middle heterolith

Lower grainstone

Lower heterolith

Ustya Fm. facies below the Makarivka

Mb. al. 1983

0.06

0.2

1.3

0.08

0.65

0

0.12

0.12

0.20

0

0.2

0.11

1.24

0.1 in Muksha 2 


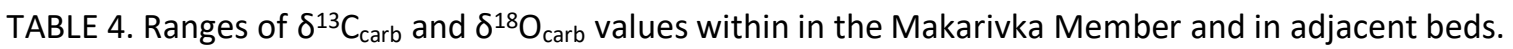

Beds are given in stratigraphic order corresponding to Fig. 6.

$\delta^{13} C_{\text {carb }} \quad \delta^{18} O_{\text {carb }}$

[\%o V-PDB] [\%o V-PDB]

Ustya Fm.

Above the conglomerate-heterolith

unit

$-1.0-1.6 \quad-7.7--3.1$

Between the lower grainstone and

$1.6-2.2 \quad-5.0--0.9$

the conglomerate-heterolith unit

Upper grainstone

0.7

$-6.5$

Upper heterolith

$1.2-1.9$

$-6.7--3.5$

Conglomerate clasts

$-0.3-2.1$

$-6.9--4.3$

Conglomerate matrix

$1.3-1.6$

$-5.3--3.6$

Lower grainstone

Ustya Fm. facies below

the Makarivka Mb.
$1.7-3.3 \quad-6.1--2.6$ 